\title{
En fodtur i Sønderjylland i sommeren 1893
}

\section{En dagbog af Vilh. Lorenzen}

I sommeren 1893 - $\mathrm{i}$ år for 100 år siden - vandrede tre store drenge ned gennem Sønderjylland, fra grænsen syd for Vamdrup og til Isted. Aret efter renskrev en af de tre, den senere arkitekturhistoriker Vilh. Lorenzen, sin dagbog fra turen. Dagbogen giver et fornøjeligt billede af de tre ungersvendes oplevelser - og den viser, hvordan sønderjysk interesserede kredse i kongeriget plejede kontakten til det tabte land tre årtier efter 1864. Dagbogen udgives her med indledning af Vilh. Lorenzens datter, lektor Gerd Kjellerup, Varde.

Arkitekturhistorikeren Vilhelm Birkedal Lorenzen (1877-1961) ${ }^{1}$ virkede hele sit liv som formidler af historisk stof: som lærer, som skribent og som foredragsholder. Gennem mange år var han lærer, bl.a. på Metropolitanskolen i København. Han fremhævede som pædagog mindesmærkernes betydning for historieundervisningen. Som forfatter og foredragsholder gjorde han gennem mere end et halvt århundrede et stort arbejde for at vække interessen for arkitekturen, dens historie og sociale betydning. De gamle borgerhuse, byernes arkitektur og byplanlægningen havde hans store interesse; han var medstifter af »Dansk byplanlaboratorium " (1921). Han skrev talrige værker om kirker, klostre, slotte og herregårde. Gennem "Foreningen til gamle bygningers bevaring « (1907ff) arbejdede han for bygningsfredning, og gennem landsforeningen "Bedre byggeskik " (1915ff) fik han stor betydning for udbredelse af kvalitetsbyggeri på landet og i de nye stationsbyer.

I dagbogen her møder vi den 16-årige Vilh. Lorenzen, der sammen med sine to fætre Svend og Gram Nygaard, alle præstesønner, foretog en rejse gennem Sønderjylland. Sine indtryk derfra har han nedfældet og senere renskrevet i 1894. ${ }^{2}$ Dagbogen viser, at han allerede tidligt har haft historisk interesse, sans for byer og bygningsværker og forståelse for sammenhængen mellem mennesker og kulturudtryk.

De tre unge mennesker ${ }^{3}$ gik over grænsen ved Vamdrup og derfra syd på over Christiansfeld, Haderslev, Aabenraa, Dybbøl, Sønderborg og Flensborg og videre mod Isted. Her slap pengene op, og de måtte vende om uden at være nået frem til Dannevirke, som havde været deres mål. Undervejs opsøgte de historiske steder, genkaldte sig begivenheder fra de sønderjyske krige, 
frydede sig over den smukke natur og mødte flere af disse års kendte danske i Sønderjylland. Også en vandreturs besværligheder oplevede de!

Interessen for sønderjyske forhold kan Vilh. Lorenzen have haft fra sin far, Claus Nicolai Lorenzen, ${ }^{4}$ som var præst i Nørre Lyndelse på Fyn. C.N.Lorenzen var født og opvokset i Løgumkloster og følte sig hele sit liv knyttet til sin barndomsegn og til Sønderjylland. I familien fortælles om ham, at han stod sammen med en ven på højen i sin have på Midtfyn og pegede mod sydvest. Hvad ligger dér? spurgte han. Da han ikke fik svar, sagde han: Dér ligger "Kloster«! C.N.Lorenzens far var Volle Lorenzen, ${ }^{5}$ landbruger og senere postkører i Løgumkloster; i omtalen af ham nævnes hans varme, danske sind. ${ }^{6}$ Også C.N.Lorenzens mor, Kirstine Nicolajsen ${ }^{7}$ var fra Logumkloster, datter af en kendt kniplingshandler. Gennem hendes mor igen var familien knyttet til Brødremenigheden i Christiansfeld.

Desuden var Vilh. Lorenzens morfar, pastor Vilh. Birkedal i Ryslinge, ${ }^{8}$ meget optaget af nationale spørgsmål. Han var kompromisløst ejderdansk og følte sig i sommeren 1864 foranlediget til at foretage en særpræget tilføjelse til kirkebønnen: "Gud give Kongen et dansk Hjerte, om det er muligt«, bad han. Som medlem af rigsrådets folketing stemte han imod fredsaftalen med Prøjsen og Østrig efter krigen i 1864.

Billedet viser den unge Vilh. Lorenzen, antagelig omkring 1895, da han blev student fra Odense Katedralskole, altsá få år efter hans fodtur i Sonderjylland. Foto Chr. Hansen, Odense. Privateje.

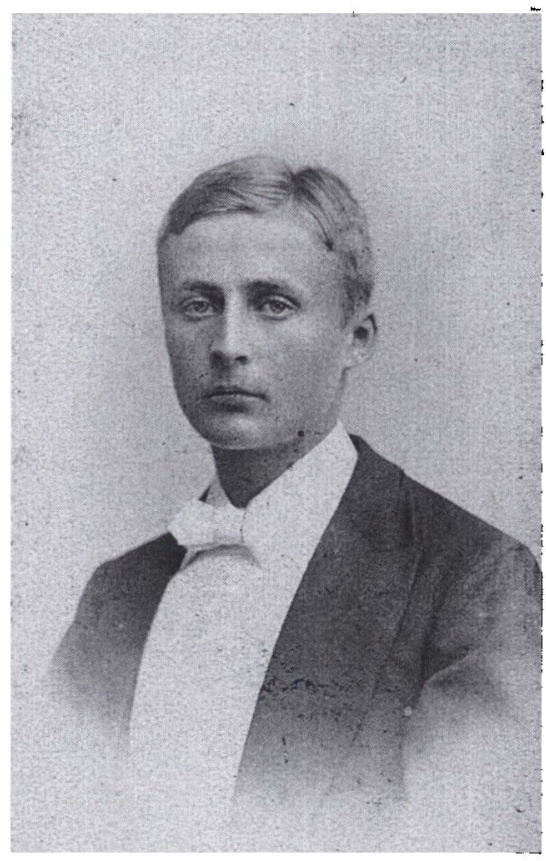


Med den baggrund er det forståeligt, men også tankevækkende, at de unge mennesker i 1893, næsten 30 år efter krigen i 1864, ikke blot havde interesse for, men også indsigt $\mathrm{i}$ de begivenheder, der havde været så afgørende for Sønderjyllands forhold til Danmark.

\section{Dagbog over en rejse i Sønderjylland sommeren 1893 af Vilh. Lorenzen samt 2 kammerater}

\section{Onsdagen den 19. juli 1893}

En middagsstund gik tre unge mennesker hen ad den landevej, som fører fra Vamdrup til Kristiansfeldt, hver med en taske over skulderen, hvori der, som det senere skulle vise sig, fandtes mange rare sager.

Disse tre unge fyre var mine to fatre Svend og Gram Nygaard samt min ringhed, og dette var begyndelsen til en fodtur, som det var meningen skulle gå ned langs østkysten af Sønderjylland og, såfremt pengene strakte til, helt ned til Dannevirke. Tidligt om morgenen var vi kørt med toget fra Løsning station og var nu ved middagstid her ved den sidste station i Kongeriget, hvorfra vi så på vore ben skulle gå til en gård, der hed Bukshave og lå et sted på den anden side af Kristiansfeldt; men det var også alt, hvad vi vidste. Her skulle vi tage ind hos Laurids Skaus broder, P. Skau, der engang havde besøgt min onkel og tante, og hvor vi sandsynligvis ville kunne tilbringe natten. For yderligere sikkerheds skyld havde min tante skrevet et brev til ham om, at vi kom, men det var højst usikkert, at det ville komme for os.

Vi stod altså på den omtalte landevej eller rettere sagt gik, og tænkte, at det vel ikke ville vare længe, inden vi kom til grænsen og så de meget omtalte sorte og hvide pæle.

Vi bestemte derfor, at vort første måltid skulle indtages på den anden side af grænsen, og da sulten allerede begyndte at trykke os lidt, gik vi rask til, idet vi bestandig så efter de omtalte sorte og hvide pæle, men vi gik og gik og så ikke spor til dem. Da vi spurgte en mand om, hvor langt vi havde til grænsen, og fik til svar, at det var en halv mil, og lidt længere henne, at det var 3 fjerdingvej, blev det vedtaget, at måltidet alligevel skulle indtages $i$ fædrelandet, hvad det også blev, og vi lod tantes smørrebrød og solbærrene vederfares al retfærdighed.

Styrket af måltidet gik vi videre, og efter mange gange at have spurgt om vej, kom vi til landsbyen Ødis, hvis kirke så meget mærkværdig ud og med sit mærkelige tårn mere lignede en købstadkirke end en landsbykirke. Herfra gik vi videre, efter af en snedker at have fået besked om, hvad vej vi skulle gå de næste par mil, hvad vi naturligvis ikke kunne huske; og efter at være 


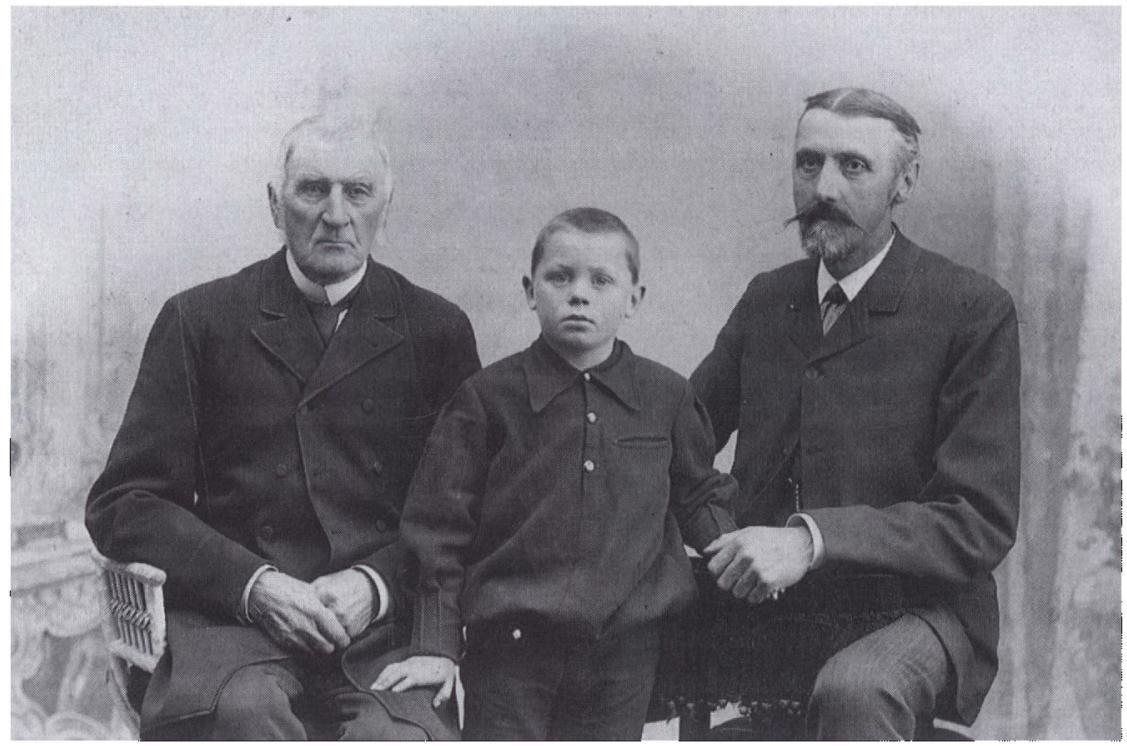

Peder Skau (1825-1917) ejede go̊rden Bukshave i Fjelstrup fra 1856 til 1903. Han var bror til den beremte Laurids Skau fra Sommersted, pioneren fra den tid „da Sonderjylland vågneder. Skau bekiadte mange tillidshverv, og hans navn stod pd titelbladet af forste årgang af Sonderjyske Arboger $i 1889$. Den gamle Skau sidder her til venstre sammen med sennen Jens og barnebarnet Laurids. Foto ca. 1907 i privateje.

gået en god tid, så vi pludselig en stor tyk pæl med den sorte ørn på. $\mathrm{Nu}$ vidste vi hvor vi var.

Med en lidt benovet følelse gik vi over i »das grosse Vaterland«, og straks kom vi i spektakel med de tyske myndigheder: Lige på den anden side af grænsen lå nemlig en landsby ved navn Frørup, og her stødte vi straks på en tysk gendarm, der spankulerede op og ned ad gaden med et ladt gevær over skulderen. Såsnart han så os, råbte han: Halt, halt! som om vi var forbrydere, der var blevet grebet på fersk gerning; men efter at han havde undersøgt vore tasker, som ikke indeholdt andet end et par af de nødvendigste klædningsstykker og en flaske brændevin, som tante, for det tilfælde at vi skulle få ømme fødder, havde givet os med, og som fik gendarmens tænder til at løbe i vand, fik vi lov til at fortsætte vor vandring.

Nu var vi altså i det tyske rige, men det var ikke til at se, hvis man ikke vidste det. Kun da vi kom hen til sprøjtehuset, så vi, at der dér var slået en plakat op, hvorpå både landsbyens navn, valgkredsen og flere andre ting stod trykt, og dette $\mathrm{i}$ forbindelse med et par tyske gendarmer var det eneste tegn på, at vi var $\mathrm{i}$ et andet land. Både huse, marker og veje så fuldstændigt ud 
som i Kongeriget, og da befolkningens sprog er dansk, måtte vi tit huske os på, hvor vi var.

Turen gik imidlertid videre, og efter at vi havde spist vore sidste stykker smørrebrød, kom vi kl. 5 til Kristiansfeldt. Det er en gansk mærkelig by; der er kun een hovedgade, som går igennem hele byen og er beplantet med lindetræer ved siden. Husene er som uddøde, og de enkelte mennesker, der går på gaden, ser ud som munke eller eneboere. Her florerede jo i slutningen af forrige og i begyndelsen af dette århundrede den herrnhutiske menighed, som var midtpunktet for al åndelig bevægelse i den del af landet.

Vi havde i lang tid glædet os til at få nogle af de berømte honningkager at smage, som byen er så berømt for. Gram blev derfor sendt ind efter nogle, og efter at vi var kommet et stykke udenfor byen, spiste vi dem med udmærket appetit ved randen af Tapsåen.

Men vi skulle jo videre, og efter at have spurgt om vej, gik vi igennem landsbyerne Aller og Stubbum, hvor vi fra en høj banke havde en glimrende udsigt over det flade land lige til Skamlingsbanken. Vi blev her ikke så lidt forundrede , da vi så Lillebælt ligge omtrent neden for vore fødder; vi havde nemlig intet kort og havde $\mathrm{i}$ grunden ingen anelse om, hvor vi havde gået, men så nu at turen var gået langs med grænsen, og at vi, trods det at vi havde gået en hel eftermiddag, kun var en halv mil fra grænsen. Uheldigvis begyndte det nu at regne lidt, og vejret blev efterhånden alt andet end behageligt, da det begyndte at blive aften, og vi endnu ikke vidste, hvor langt vi havde til Bukshave, som skulle ligge i Fjelstrup eller Tyrstrup sogn.

I stadigt regnvejr gik turen gennem landsbyerne Lille Anslet og Knud, og efter mange gange at have spurgt om hvor P. Skau boede, fik vi tilsidst anvisning på et par gårde, hvoraf den ene skulle være Bukshave. Først gik vi naturligvis ind $\mathrm{i}$ den gale gård, hvor konen blev ikke så lidt forfærdet ved at se sådan tre landevejsrøvere træde ind ad døren, og det var vist med hemmelig glæde, at hun fortalte os, at vi var gået fejl.

Endelig stod vi da i det rigtige "Bukshave« og vakte også her en ikke ringe forbavselse. Straks sagde vi, hvem vi var og spurgte, om der ikke var kommet et brev til P. Skau om vor ankomst; men P. Skau var ikke hjemme, og der var ikke en sjæl, der anede vor tilværelse.

Alligevel blev vi med uhyre venlighed af hans husholderske vist ind i stadsstuen, hvor vi skulle vente på P. Skau, der ventedes hvert øjeblik. Der sad vi så, og var ikke rigtig glade ved situationen, og til at stemme humøret endnu mere ned kom det, at vore fødder ikke var fri for at være ømme efter den lange tur; vi havde nemlig gået en $31 / 4 \mathrm{mil}$, og når man ikke er vant til at gå, er det jo lidt meget på een gang.

Imidlertid kom Peter Skau og var uhyre gæstfri. Vi måtte endelig blive der 


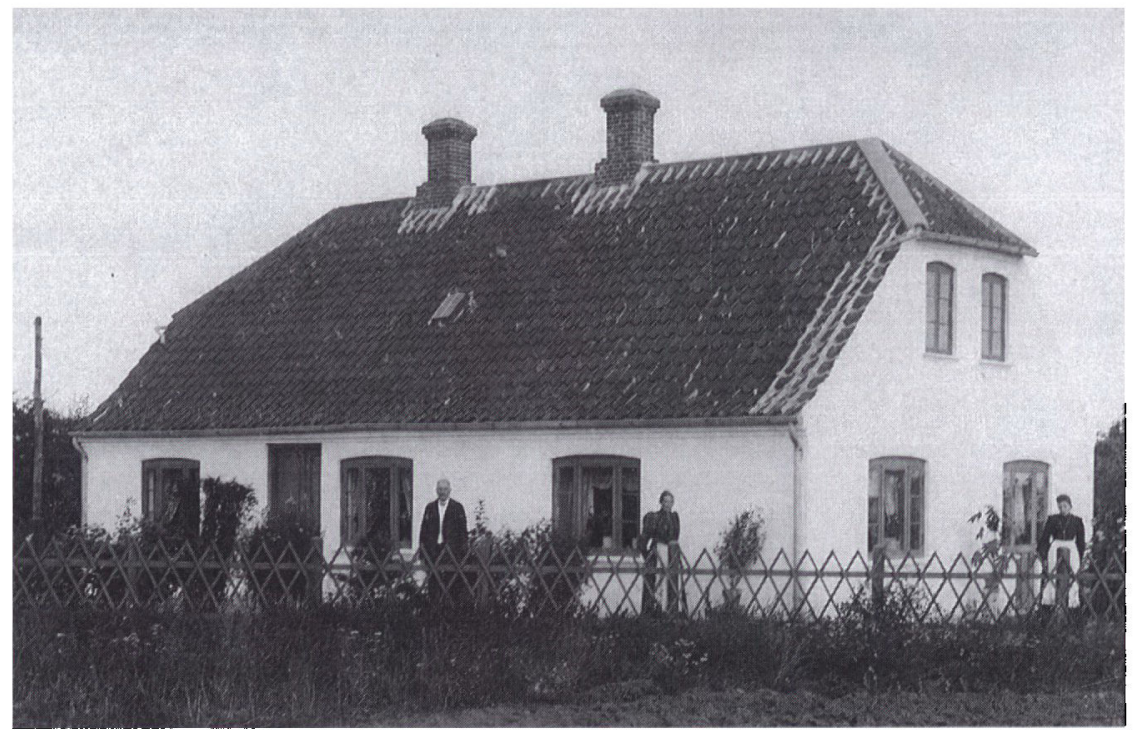

Vilh. Lorenzen og hans venner var blot nogle blandt mange besøgende nordfra, som i Peder Skaus tid fandt husly pd gården Bukshave i Fjelstrup. Skau ydede ogsd stotte til unge sonderjyder, som ville gore en indsats for danskheden. Det gjaldt f.eks. den senere redaktor A. Svensson, for hvem Bukshave blev wet larested i senderjysk historiew (SJy Arb 1989 s. 279).

Der er ikke bevaret billeder fra Bukshave i Skaus tid. P\& billedet her er Skau fotograferet foran aftagtshuset i Fjelstrup, med husholdersken, jomfru Hüseler, i midten. Foto ca. 1915. Privateje.

om natten; han havde altid gæsteværelser parate til turister oppe fra Danmark, og han vidste ikke alt det gode, han ville gøre os. Om natten sov vi i de bedste senge, jeg nogensinde har ligget $i$, og da vi om morgenen vågnede, var al træthed borte, men regnen strømmede endnu ned. Op på formiddagen klarede det dog op, og efter hver at have fået en vældig pakke smørrebrød med, begav vi os afsted for igennem Haderslev at komme til Aabenraa, hvor der skulle bo en journalist H. P. Hanssen-Nørremølle i Nygade; men det var også alt, hvad vi vidste, og han skulle så sørge for, at vi fik natteleje på en eller anden måde. For resten havde vi en hel del anbefalingsbreve til flere kendte mænd dernede, og som tante havde skrevet; men da vi altid syntes det var så flovt at komme frem med dem, og heller aldrig havde nogen særlig brug for dem, blev de slet ikke brugt.

\section{Torsdag den 20. juli}

Vi drog altså afsted om formiddagen i det dejligste vejr. Regnen havde gjort alt så friskt, og nu da solen skinnede, kunne vi ikke ønske et bedre vejr at gå i. Vi nød også tilværelsen og gik rask til. Vi kom derfor efter kort tids forløb 
til landsbyen Sillerup og herfra til Åstrup, hvor general Krogh er født. Oppe fra den høje Åstrup Banke har man en glimrende udsigt over en stor del af det omliggende land. Men Haderslev, der kun ligger en halv times vej derfra, kan man ikke se, da byen ligger meget lavt bag ved en anden bakke.

Efter at vi var gået et lille stykke til, så vi imidlertid byen med dens kirketårne og kasernen, der rager op over hele byen. Inden vi gik ud i byen, spiste vi frokost, og med friske kræfter vandrede vi videre og stod snart $i$ byen. Det er kun en lille købstad, og der er ikke meget seværdigt foruden kirkerne. På torvet blev vi behageligt overraskede ved at se en statue af Kejser Wilhelm I opstillet, og her købte vi os et stort franskbrød, som skulle udgøre vor næring lige til Aabenraa.

Efter at vi havde fået en del af vore penge vekslede og havde set os om $i$ byen, gik vi videre over en smal bro mellem fjorden og den lange smalle "Dam«, der ligger bag ved byen. Vi var imidlertid ikke gået ret langt, førend det igen begyndte at trække op, og snart begyndte det at regne, hvad det blev ved med lige indtil Aabenraa.

Under en voldsom byge kom vi til landsbyen Hoptrup, hvor der i Treårskrigen stod en for os uheldig træfning. Her fandtes en dejlig stor kro, og da vi allerede havde gået langt og var meget sultne, ytrede jeg, at en kop kaffe ville gøre udmærket virkning. Men Svend satte sig af al magt derimod og sagde,

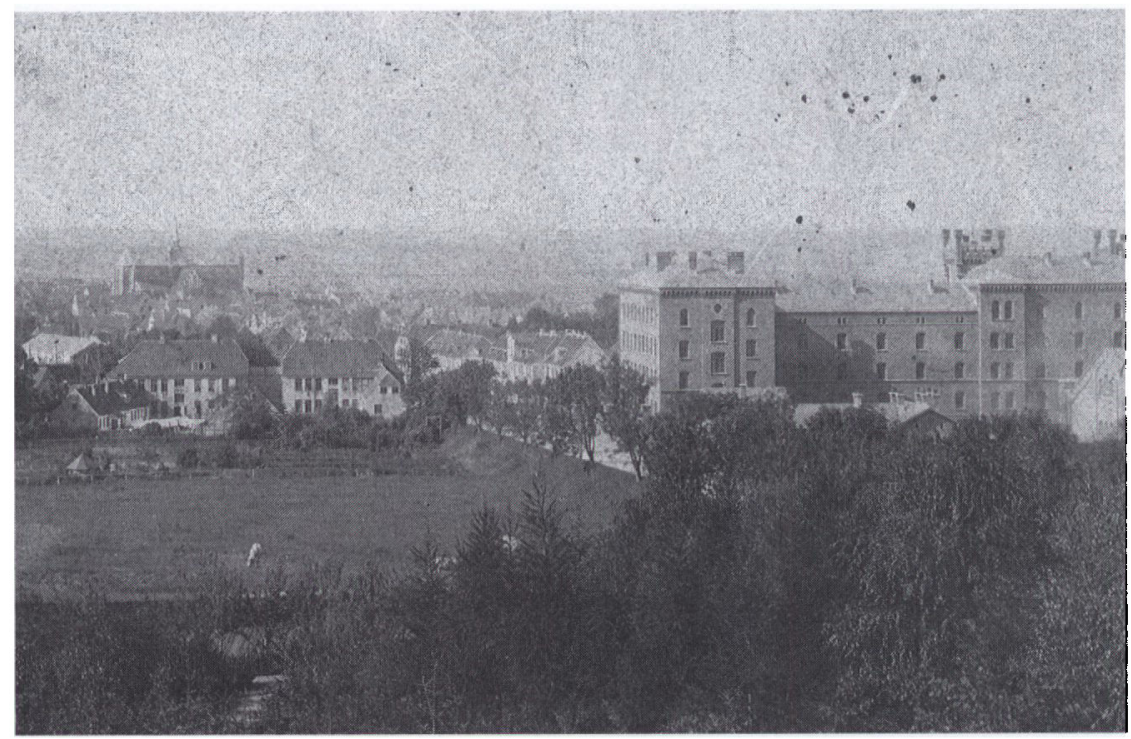

Omtrent sådan oplevede de tre vandringsmand Haderslev, da de kom til byen nordfra. Byen kryber sammen mellem domkirken til venstre og kasernen fra 1888 til hojre. Foto o. 1890 i Haderslev byarkiv. 
at vor pengekasse på ingen måde kunne holde ud til en så vældig udgift. Efter lang strid, og efter at være blevet gennemblødt til skindet alle tre ved at stå stille udenfor kroen, blev det vedtaget, at vi skulle have kaffe. Jeg vil ikke nægte, at skønt jeg altid har holdt meget af kaffe, så har den ikke mange gange smagt mig så godt som i Hoptrup kro, og det var ligefrem med en slags glæde, at jeg følte mig 30 pfenning fattigere.

Dér i kroen hvilede vi ud, indtil vejret blev bedre og fortsatte så vor vej. Inden ret længe kom vi til den høje banke, Knivsbjerg, som ligger lige ud for Gennerfjord, efter at vi flere gange havde taget os en hjertestyrkning af det omtalte franskbrød. Vi satte os nemlig ind under buskene ved vejkanten, og mens regnen plaskede ned rundt om os, skar vi med vore tolleknive brødskiver af og spiste dem med største velbehag. Og da dette gentog sig hele vejen ned til Aabenraa, kan det ikke nægtes, at vi havde god nytte af det brød.

Ved Gennerfjord mødte vi en mand med et stort kobbel heste, men netop da vi mødte ham, rev den ene hest sig løs, tumlede ned af den høje vejskrænt og løb bort, alt hvad den kunne. Manden bad så os om at holde ved de andre heste, mens han søgte at indhente den, der var løbet bort. Men det var lettere sagt end gjort for os at holde sådan et stort kobbel roligt, og vi måtte da også opgive det. Heldigvis kom der en vogn kørende, og folkene på den hjalp os; men så måtte vi holde deres heste, og mens hestehandleren anstrengte sig for

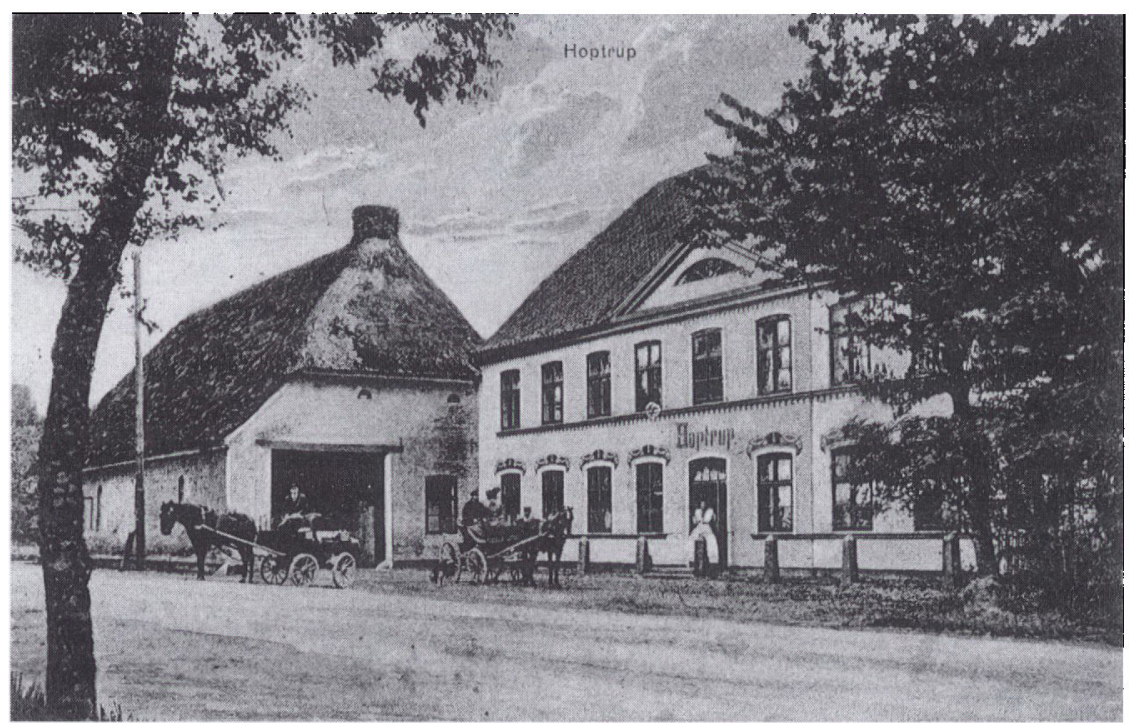

Den »dejlige store krow i Hoptrup. Her blev Hoptrup hojskole indrettet i 1919-20. Postkort i Historiske Samlinger for Sonderjylland. 
at fange den bortløbne hest, og regnen af og til strømmede ned, stod vi der frysende og gennemblødte.

Men alting får en ende, og efter at vi havde stået på landevejen i 1 time, kunne vi endelig fortsatte vor vej; men heldigvis tabte vi ikke modet, og vi tog det hele med gemytlighed, skønt det ikke er rart at spadsere et par mil gennemblødte indtil skindet. Vi var oppe på en høj bakke, hvorfra man havde en god udsigt, men det var desværre noget tykt i vejret, så udsigten den dag ikke var så god. Fra Genner gik vi videre forbi den store kirkeby Løjt, og vejen går her hen over store mose- og hedebakninger, der dannede en stor modsætning til de frugtbare marker og smukke egne, vi tidligere havde passeret.

Men imidlertid begyndte det at blive aften, og vi langtes meget efter at komme til Aabenraa, som vi efter vor rejsebog snart måtte komme til, og endelig ved en omdrejning af vejen så vi byen og fjorden ligge for os. Det gjaldt nu blot om at finde hvor $H$. P. Hanssen boede. Efter at vare gået omkring i byen, hvor stenbroen gjorde de i forvejen ømme fødder endnu mere ømme, traf vi tilfældigvis på Nygade, men Nygade var lang, og vi var forholdsvis lige vidt. Nogle folk vi spurgte om besked vidste ikke, hvor H. P. Hanssen boede, og tilsidst gik jeg ind i et hus for at få det at vide. Men huset var som uddødt og først ude $i$ gården traf jeg et menneske, som imidlertid ikke forstod et ord dansk. Jeg begyndte så at tale tysk, men trods det, at jeg lige havde taget afgangseksamen i dette fag, måtte jeg bekende, at jeg ikke var sproget rigtig mægtig, men jeg fik dog at vide, at han heller ikke kendte manden, og vi var altså lige vidt. Så spurgte vi en mand til om besked, men da han heller ikke vidste det, spurgte han en anden mand og denne igen andre, så der tilsidst samledes en hel forsamling, der rådslog om, hvor H. P. Hanssen vel kunne bo, men uden resultat.

$\mathrm{Nu}$ var vi lige ved at opgive ævret, og begav os på opdagelse efter et gæstgiversted, som der forresten var masser af, da Svend gjorde et sidste forsøg og spurgte en mand om besked. Han vidste det til vor store glæde og viste os op i det hus, vi havde stået overfor den sidste halve time. Her gik vi så op og traf H. P. Hanssen hjemme. Han beklagede meget, at han ikke kunne have os om natten, da der var et par finske damer på besøg, men han anviste os et pænt gæstgiversted, hvor vi kunne tilbringe natten.

Hos H. P. Hanssen blev vi et par timer, og både han og hans kone var meget venlige imod os. Da vi rejste os op for at gå, var vi blevet så stivbenede af hvilen, at den korte vej hen til gæstgiverstedet var en ren tortur. Her fik vi så efter nogen snakken 2 værelser, og efter at have spist det sidste stykke af vort franskbrød gik vi i seng. Vi pålagde imidlertid pigen at kalde på os klokken 5 om morgenen, da vi kl. 6 skulle sejle med dampskib til Sundeved 


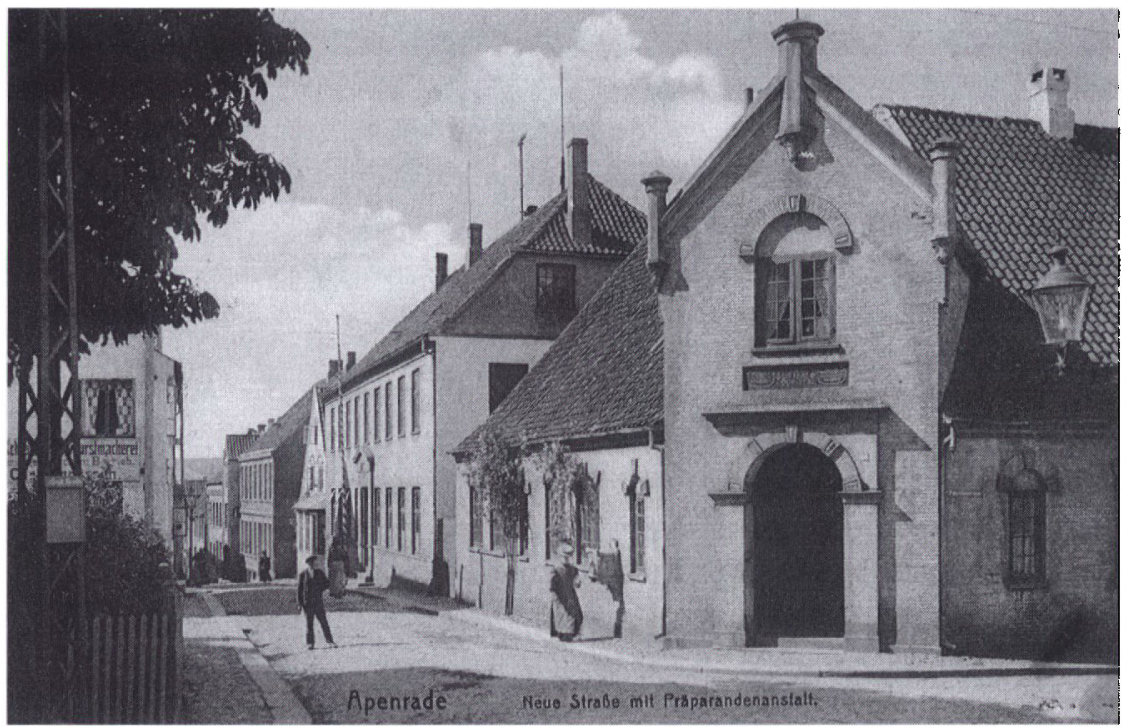

Nygade i Aabenraa set fra hjornet foran H.P. Hanssens hus (nr. 41). Selv om wden sonderjyske forerk var ret sả kendt allerede $i$ 1893, måtte de tre ungersvende sporge en hel rakke folk $i$ Aahenraa, for de fandt vej til hans bopal. Postkort $i$ Historiske Samlinger for Sonderjylland.

og derfra gå ned til Broager, hvor der boede en mand, vi havde anbefalinger til. Der er få gange i mit liv, hvor jeg har været så træt som den aften, men den dag havde vi også gået $4 \frac{1}{2}$ mil, så vi kunne nok trænge til søvn.

\section{Fredag den 21. juli 1893}

Om morgenen blev vi altså vækket kl. 5, og det var ikke med det bedste humør vi stod op, men så tidlig på morgenstunden er man i reglen lidt morgengnaven. Da vi havde fået vor kaffe sat til livs og hver havde betalt en krone, var humøret dog straks igen udmærket, og vi begav os ned til havnen, hvor damperen lå og ventede. Straks efter sejlede vi ud ad den for sin skønhed berømte Aabenraa fjord, og et smukt syn var det også, når solen brød igennem skyerne og skinnede på bøgeskove og kornmarker, mens byen med sine røde tage lå bagved os og bidrog til at gøre synet endnu kønnere. Sejladsen gik altså ud af fjorden, og ved Varnæs, hvortil der knytter sig sagnet om Ridder Viggo, drejede damperen ud i den øverste del af Alsfjord.

Det havde af og til regnet lidt, men nu blev det det dejligste vejr, man kunne tænke sig, og snart efter landede skibet ved Ballebro, hvor vi skulle af. Af vor rejsebog så vi, at der skulle gå en sti fra stranden af og op til byen Blans, og efter nogen søgen fandt vi den også, men om det var den rigtige, er jeg endnu meget i tvivl om. Stien blev nemlig bredere og bredere, og tilsidst stod vi midt 
inde $i$ en stor have, og ligefor lå stuehuset. Vi var nemlig kommet ind i gården "Ballegaard «, som vi senere erfarede ejedes af en meget tysksindet mand, som rimeligvis ikke ville have behandlet os ganske pænt. Vi slap dog lykkeligt ud af haven ved at springe over et garde og kom til sidst op i byen Blans.

Straks ved vor landgang stod vi i strængeste forstand på historisk grund; thi ved Ballebro havde prøjserne i 64 i sinde at foretage en overgang til Als, som dog på grund af storm måtte opgives. Til hvert eneste stednavn i Sundeved knytter der sig mindet om en eller anden historisk begivenhed og jo især fra vore sidste krige, da denne lille halvø, navnlig i 64, var genstand for hele verdens interesse.

Fra Blans, hvor maleren Eckersberg er født, gik vi videre til landsbyen Ullerup. Her besøgte vi $H$. P. Hanssens svoger, til hvem vi havde et brev fra fru Hanssen. Manden, der hed Johan Iversen, var uhyre gestfri imod os, og straks fik vi et forsvarligt foder, som vi også nok kunne trænge til, og han ville absolut beholde os i nogen tid, men vi havde besluttet den dag at nå til Broager, og vi havde derfor kun lidt tid at give bort.

I det dejligste vejr gik vi altså videre og beundrede $\mathrm{i}$ høj grad landets

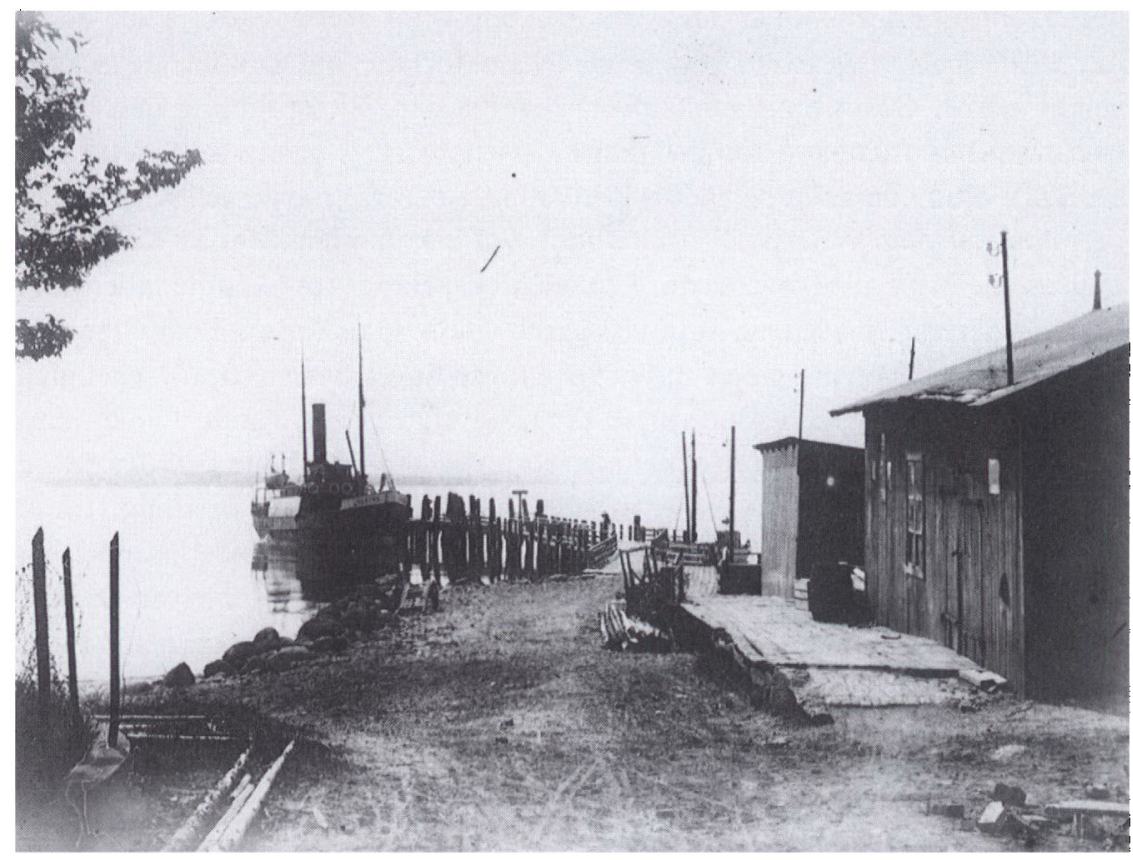

Dampskibet "Hertha" ved landingsbroen $i$ Ballebro. Foto C. C. Biehl $i$ Historiske Samlinger for Sonderjylland. 
skønhed. En mærkelighed ved Sundeved er de mange levende hegn; thi ikke alene vejene omgaves af store hassel- og tornehegn, men også imellem de enkelte marker findes der levende hegn, og når man kommer op på et højt punkt, forskønner de landskabet $\mathrm{i}$ høj grad. De havde i krigsårene stor betydning, idet de snart skjulte vore soldater for fjenden og snart deres for vore folk.

Snart kom vi til landsbyen Sottrup, fra hvis kirketårn der er en storartet udsigt ud over hele Alssund, Als og selve Sundeved. Her var vi naturligvis oppe og skrev adskillige patriotiske udbrud på bjælkerne. Krigergravene på kirkegårdene så vi altid, hvor vi kom hen; men der var ikke alene grave på kirkegården; også rundt om på markerne og ved vejene traf vi hvert øjeblik på en simpel lille sten, der meldte, at her lå så og så mange faldne soldater, og det var kun en ringe del af de faldne, hvorover der stod en gravsten; thi mange var uden videre blevet gravet ned på marken, når man fandt dem, og deres grave er blevet glemt for længe siden.

Fra Sottrup kom vi til Ragebøl, hvor vi tog ind hos Matias Kristensen, ${ }^{10}$ der var blevet os anbefalet af $\mathrm{H}$. P. Hanssen. Her blev vi også udmærket gæstfrit modtaget, og hverken han eller hans kone vidste alt det gode de ville gøre os. Naturligvis var det ikke altid så let at finde samtaleemne, når vi kom ind til vildfremmede folk, men det gik dog altid rigtig godt. Hver af os havde altid noget vi kom frem med. Svend fortalte om vor hændelse med gendarmerne, Gram om landets mærkværdigheder, og jeg udtalte min glæde over valgenes fremgang for det danske parti. Når vi havde sagt dette, gik samtalen altid udmærket, og det var morsomt nok, at vi havde fælles bekendte, og mange af dem vi kom til kendte godt den hele familie. Matias Kristensen opfordrede os til at besøge pastor Claussen i Dybbøl " som kendte fader godt og hvor der var en student, som vist gerne ville vise os om på Dybbølbanke.

Her gik vi altså hen og blev uhyre venligt modtaget. Præsten var meget glad over vort besøg, og studenten var straks villig til at vise os rundt. Under hans anførsel beså vi Dybbølskanserne, som jo nu er sløjfede, både dem fra $64 \mathrm{og}$ de, prøjserne senere byggede for at omdanne banken til en fæstning. En af dem står dog som et minde om befæstningen, og den var vi inde $i$, men ellers ser det hele ganske fredeligt ud. Man må imidlertid indrømme, at Dybbøl Banke i en krig har stor betydning; den danner nemlig en trekant, der skråner ned mod Alssund og Vemmingbund, og den behersker hele omegnen fuldstændigt. Man har også deroppefra en storartet udsigt over Als, Broager, Østersøen og langt ind $i$ landet, og det er med en vemodig følelse man husker på, at dette smukke og frugtbare land er under fremmed herredømme, skønt befolkningen er så dansk, både i sind og tale.

Oppe på højen knejser tyskernes »Denkmak«, en meget høj pyramideformet 
stenstøtte, med relieffer, der fremstiller de vigtigste begivenheder under belejringen af skanserne. På et af dem er løjtnant Ancker fremstillet på en meget rosende måde, hvad der viser tyskernes agtelse ikke blot for løjtnant Ancker alene, men for hele forsvaret af stillingen. Det er naturligvis ikke med blide øjne, at den danske befolkning ser på dette monument, og der er mange dernede, som ser til den anden side, når de går forbi den. Det kan forresten ses i stor omkreds, og det er næsten, som om tyskerne stadig må mindes om, at det er dem, der er herrer. Thi ved Arnkilsøre har de opstillet et lignende monument, og står man på Dybbøl Banke, kan man tydeligt se det, så det ser ud, som om de stadig må mindes om virkeligheden. Thi hvor de end måtte stå og gå i Sundeved, kan de se i det mindste et af disse monumenter. Men lige ved siden af »Denkmalet « ligger Dybbøl mølle som et minde om danskheden $\mathrm{i}$ Sønderjylland, og den kan ses vel så langt borte som tyskernes monument.

Efter at have set de mange krigergrave på bankens top, den store sten, hvor Frederik d. 7. engang spiste til aften tillige med sine hoffolk, tog vi afsked med vor fører og begav os ned til Sønderborg, hvor vi så os om $i$ byen og var henne ved det berømte gamle slot, der nu bruges til kaserne. Slottet selv er bygget af røde sten og er en grim, mørk firkantet bygning. Levningerne af ringmuren står endnu, og i den gamle slotsgård eksercerede nu de prøjsiske soldater.

Efter igen at være gået over pontonbroen og have betalt vore bropenge, gik vi tilbage over Dybbølbanken og forbi Frydendal Kro og Avnbjerg, der er bekendte fra sidste krig. Ad en sti gik vi langs med Vemmingbund, hvor vi vaskede vore fødder, hvad der friskede betydeligt og stod nu på halvøen Broager. Det var vor hensigt at nå frem til en mand, der hed Andresen og boede på Skellemark. Da vi spurgte om, hvor det var, blev der svaret, at det lå pokker $\mathrm{i}$ vold ude ved Flensborg fjord.

Situationen begyndte nu at blive lidt uhyggelig; thi klokken var 8 , og vi ville rimeligvis først nå vort bestemmelsessted sent om aftenen, hvad der ikke var så rart, da vi slet ikke kendte folkene. Langt om lange efter at være gået igennem byerne Dejret [Dynt?] og Skelle og mange gange at have spurgt om vej, kom vi endelig til en gård, som lå helt ude ved fjorden, og som også var den rigtige. Konen var ene hjemme og blev meget forfardet, da hun så os 3 vildfremmede mennesker. Men da hun hørte, hvem vi var, og at vi gerne ville tilbringe natten der, lod hun os vente, til hendes mand kom.

Vi satte os altså ind og var meget glade ved at kunne hvile os lidt; thi da vi havde været oppe kl. 5 og havde gået hele dagen, var det ikke mærkeligt, at vi var lidt trætte. Da vi havde ventet en stund gik døren op, og Svend, der sad $i$ en stor armstol, rejste sig gravitetisk op og begyndte en lang tale om, hvem vi var, og hvad vi ville, som imidlertid pludselig blev afbrudt ved at 
manden, der var kommen ind, oplyste os om, at han kun var karlen på gården. Inderlig flov satte Svend sig ned igen og snart efter kom den rigtige Andresen. ${ }^{12}$ Han blev meget glad ved at se os, og opvartede os med cigarer og mælkebrød. Han var meget livlig og vi sad oppe til hen ad elleve og snakkede om alt muligt, skønt vi var så søvnige, at det var en gru. Endelig slap vi da i seng og sov udmærket.

\section{Lordag den 22. juli 1893}

Denne dag havde vi i sinde straks om morgenen at sejle ind ad Flensborg fjord og derfra at gå ned til Dannevirke. Vi så os derfor kun lidt om nede ved stranden, og blev så af Andresen fulgt hen til en gårdmand Philipsen, ${ }^{13}$ som han mente ville blive glad for at se os, da han kendte familien. Netop da vi gik ind ad porten, mødte vi ham; han sad på en vogn og skulle på en temmelig lang tur, så det var i et overmåde heldigt øjeblik vi kom. Straks blev vi budt ind, og da han hørte, at vi ville til Dannevirke samme dag, ville han absolut have, at vi skulle blive hos ham i nogle dage og gøre udflugter $i$ omegnen. Det tog vi naturligvis med glæde imod.

Efter at vi havde spist til middag, kørte han os til halvøens højeste punkt, Dyntbanke, og herfra havde vi den mest storartede udsigt, man kan tænke sig helt ned til Flensborg, til Frø og udover Als og Sundeved, og det var fuldstændig som et landkort, der var udbredt for vore fødder. På disse bakker var det, at prøjserne i 64 havde de for os så skadelige Broager-batterier, der kunne beskyde stillingen på langs, hvad vi aldeles ikke havde tankt kunne lade sig gøre.

Fra Dejret [?] blev vi kørt til den store landsby Broager. Vi beså den smukke kirke, med 2 tårne og kirkegården, hvorfra vi havde en smuk udsigt. Herfra gik vi til en lille høj ved landsbyen Smøl, der muligvis er en gammel skanse fra svenskekrigen $\mathrm{i}$ forrige århundrede og måske meget aldre. Fra den har man også en storartet udsigt til Gråsten og Ekernsund, med dens mange teglværker, hvis røde tage og høje skorstene gav landskabet et livligt præg.

I Broager besøgte vi mejeribestyrer Fabricius, hvor vi blev meget gæstfrit modtagne og måtte fortælle alle vore oplevelser til stor morskab for hele familien. Fruen ville absolut have, at vi skulle skrive i hendes stambog. Vi blev derfor lukket ind $i$ et pulterkammer og lavede der med stort besvær det frygteligste sludder, der kan skrives $i$ et vers med to linier. Efter at have gået en lille tur ved solnedgang ned ad stranden til, kørte vi tilbage til Skellemark, og dermed endte så den dag.

Sondag den 23. juli 1893

Allerede kl. 6.30 var vi oppe. Philipsen ville nemlig i kirke i Dybbøl, og vi ville gerne med. Efter kirketid ville vi så gå til den smukke herregård Sandbjerg 


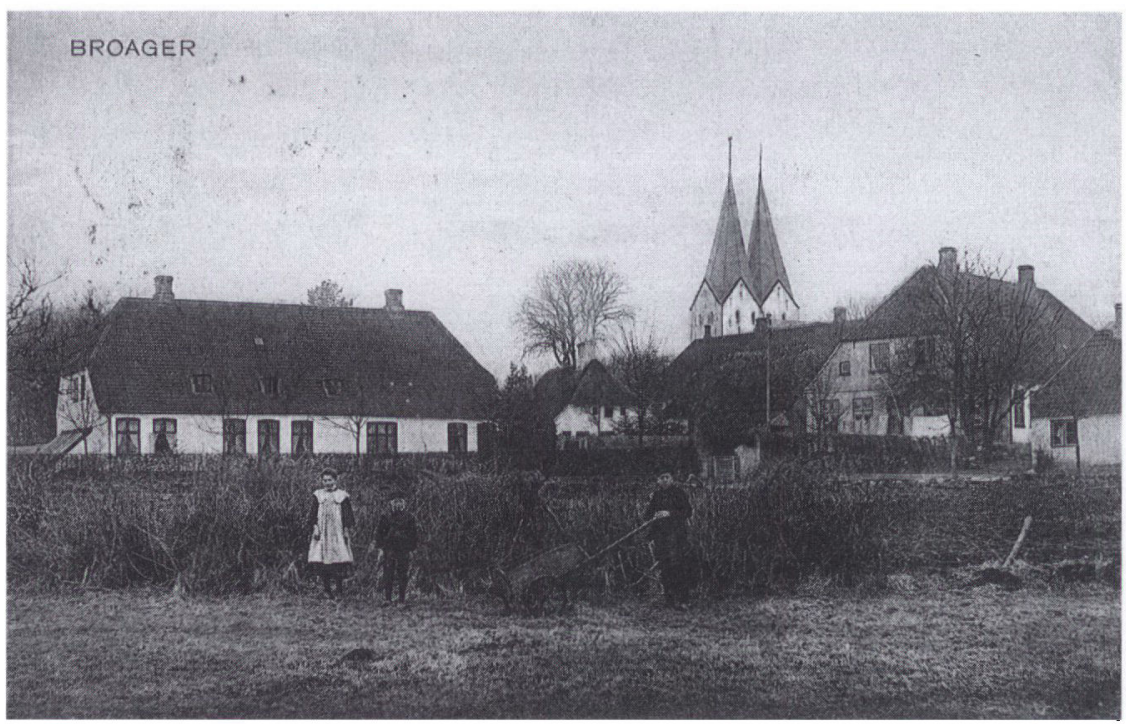

Broager kirke og de narmeste ejendomme. Postkort 1909 i Historiske Samlinger for Senderjylland.

og derfra til Augustenborg på Als. Vi var altså i kirke, og det var mærkeligt nok at høre dansk prædiken og danske salmer $i$ et fremmed land. Alt så også så hjemligt ud, så man tit havde møje med at huske, at tyskerne var herrer her.

Efter kirketid spiste vi til middag hos præsten og traf her på bestyreren af Sandbjerg, hr. Ort, ${ }^{14}$ som godt kendte fader, og som indbød os til at besøge dem og bese godset, hvad vi naturligvis med glæde tog imod. Men præsten ville imidlertid ikke give slip på os, førend vi havde drukket kaffe, og af den grund kom vi ikke af sted før kl. 3. Det var nu for sent at gå til Sandbjerg og Als den dag, hvorfor vi i stedet for bestemte at gå til Graasten og derfra sejle med damper til Brunsnæs, hvorfra vi så skulle gå til Philipsen i Skelle.

Af omtrent hele præstegårdens befolkning blev vi fulgt på vej, lige til vi kom til Bøffelkobbel skov, hvor de to grave findes, hvorom H. Drachmann har skrevet sin bekendte sang: "De vog dem, vi grov dem en grav i vor have." Gravene findes nemlig $\mathrm{i}$ haven hos et par gamle folk, der passer dem og pynter dem med Dannebrogssløjfer og kranse. Her tog vi altså afsked med vort følge og gik videre i det dejligste vejr ad landevejen forbi Nybøl og Adsbøl, hvor vi så krigergravene.

En mærkelighed ved kirkerne i Sønderjylland er, at der altid på kirkegården findes et tårnagtigt træskur, der er tjæret sort, og hvor forskellige redskaber 


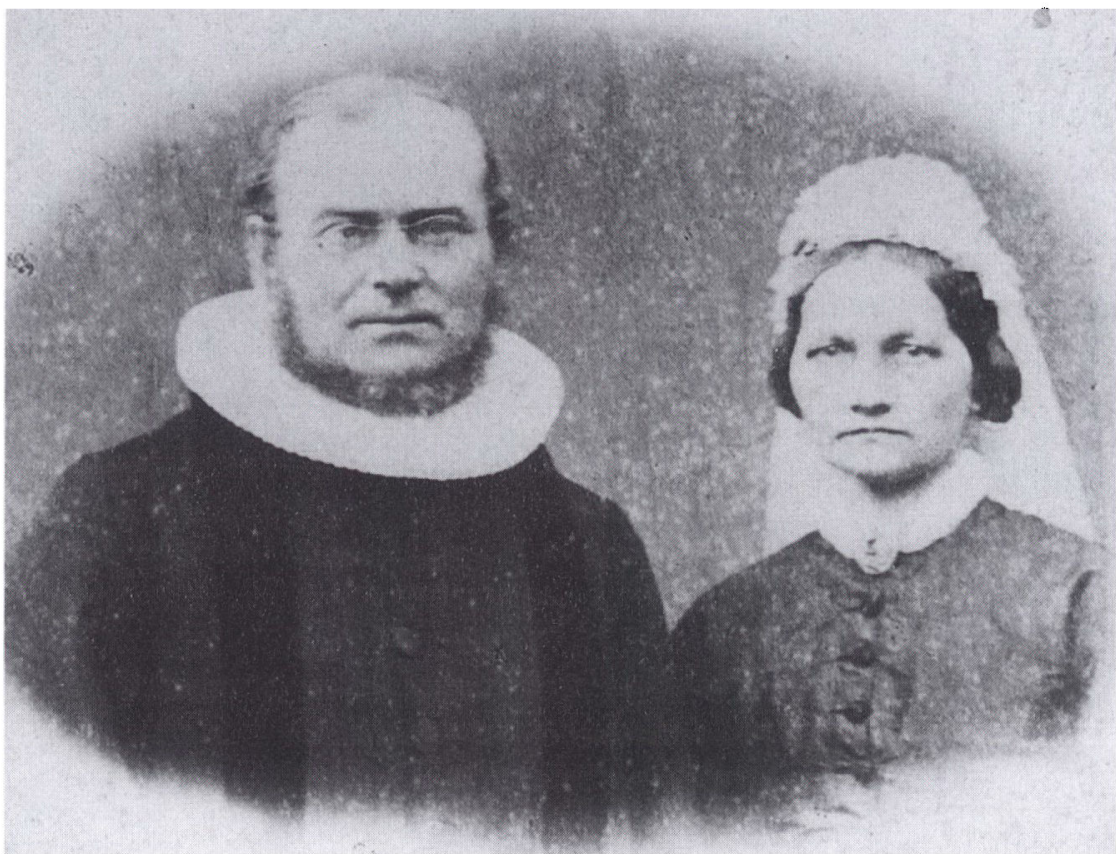

Pastor Heinrich Ferdinand Emil Claussen (1832-1902) var sogneprast i Dybbel fra 1865 til sin dod. Her er han fotograferet sammen med sin kone Karen Marie fodt Olsen. Foto i Historiske Samlinger for Sonderjylland.

opbevares. Mange af disse træskure er meget gamle, og her har vistnok engang kirkeklokkerne hængt.

Ved siden af vejen lå en lille skov, og i den tanke at vi kunne skyde genvej, gik vi herinde, men det var en sørgelig fejltagelse; thi vi for vild, og endelig langt om længe traf vi en mand, som bragte os på ret køl igen. Snart var vi også i Graasten og beså slottet, der imidlertid ikke var ret kønt. Det var en almindelig grå kasse med 3 længer og på den midterste et lille tårn. Men det har en smuk beliggenhed ved en lille sø og $i$ en stor park. Denne så vi naturligvis og var oppe på den såkaldte "Hjærtehøj«, hvorfra vi havde en "idyllisk « udsigt, som der stod i rejsebogen. Det var virkelig også et kønt syn, idet vi så ud over slottet og byen, samt Flensborg fjord og dens omgivelser. Herfra gik vi ned igennem byen til det store tyske kurhus, der ligger lige ved dampskibsbroen.

I Dybbøl havde vi fået at vide, at der i Sandager, som skulle ligge $\frac{1}{2}$ times gang syd for Graasten, fandtes en smuk udsigt over Flensborg fjord, og herfra kunne vi tage med damper til Brunsnæs. Skønt vi altså var ved dampskibsbroen 
i Graasten, besluttede vi alligevel at gå til Sandager. Men af en mand, vi spurgte om vej, fik vi at vide, at tiden var meget knap, hvis vi ville med damperen. Der blev nu sat fart på, og igennem Trappen og Ringenæs, hvor den første soldat faldt $\mathrm{i} 48$, gik det $\mathrm{i}$ løb op og ned ad bakke ad de frygteligste veje. Et stykke fra stranden råbte en dreng til os, at vi måtte skynde os, hvis vi ville med, og i strakt karriere gik det ned ad den sidste bakke.

Endelig stod vi da ved strandbredden, men der var ikke spor af dampskibsbro at se. Først da vi var kommet om bag en pynt, fandt vi den, og så til vor store glæde at damperen kom sejlende hen imod broen. Vi var altså kommet for tidligt og tog den nu med mere ro. Men, hvem skildrer vor flovhed, da damperen ganske roligt sejlede forbi broen og forsvandt ind ad Graasten til. I det fjerne så vi også røgen af den damper, som vi skulle have været med, men som vi altså kom for sent til.

Nå! tænkte vi; damperen må jo komme tilbage igen inden ret længe, og så kan det sagtens nås alligevel. Imidlertid gik vi op på de høje skrænter ved strandbredden og nød her udsigten over Flensborg fjord, halvøen Holnæs og bag ved den Broager med dens smukke kirke. Det var netop ved solnedgang, og den rødlige belysning, hvori alt sås, gjorde landskabet endnu smukkere. Men tiden gik imidlertid, det begyndte at blive koldt, så vi ikke var fri for at fryse. Det blev os lidt mistænkeligt, at damperen ikke kom, og jeg gik derfor ind i ventesalen og spurgte, om hvornår damperen til Brunsnæs gik.

Til min store skræk hørte jeg nu, at den gik slet ikke, og først $\mathrm{kl}$. 10 ville der afgå en damper til Ekernsund. Dér sad vi net i det, thi fra Ekernsund til Skellemark var der ca. $1 \frac{1}{2} \mathrm{mil}$, og vi ville altså først nå vort bestemmelsessted midt om natten. Hvad ville også Philipsen tænke om os, når vi først kom hjem på den tid. De sad måske oppe og ventede på os, bange for at der skulle være tilstødt os noget. Den slags ikke just behagelige tanker stemte vort humør en del ned, men vi tog dog det hele med gemytlighed og tænkte, at der ikke var noget så galt, uden det jo var godt for noget.

Endelig kom da damperen, og efter at være blevet forsinkede en hel del ved at nogle kom for sent, som vi måtte vente på, landede vi langt om lange $i$ Ekernsund. En mand, som vi sejlede med, og hvem vi havde fortalt vor sørgelige skæbne, skældte os frygtelig ud for vor dumhed, idet vi var løbet fra Graasten, hvorfra vi havde kunnet komme til Brunsnæs, til Sandager, hvor dette ikke kunne lade sig gøre, men han tilbød dog at køre os på vej, hvad vi naturligvis ikke ville tillade.

Efter at vi med stort besvær havde fået vor billet afleveret, stod vi på broen og skulle se at finde vej, midt om natten og på et sted, hvor vi aldrig i vort liv havde været. Vejen fandt vi dog, og halvt i løb gik turen i måneskin gennem sovende landsbyer til Skellemark, hvor vi nær var gået ind i en gal gård. 


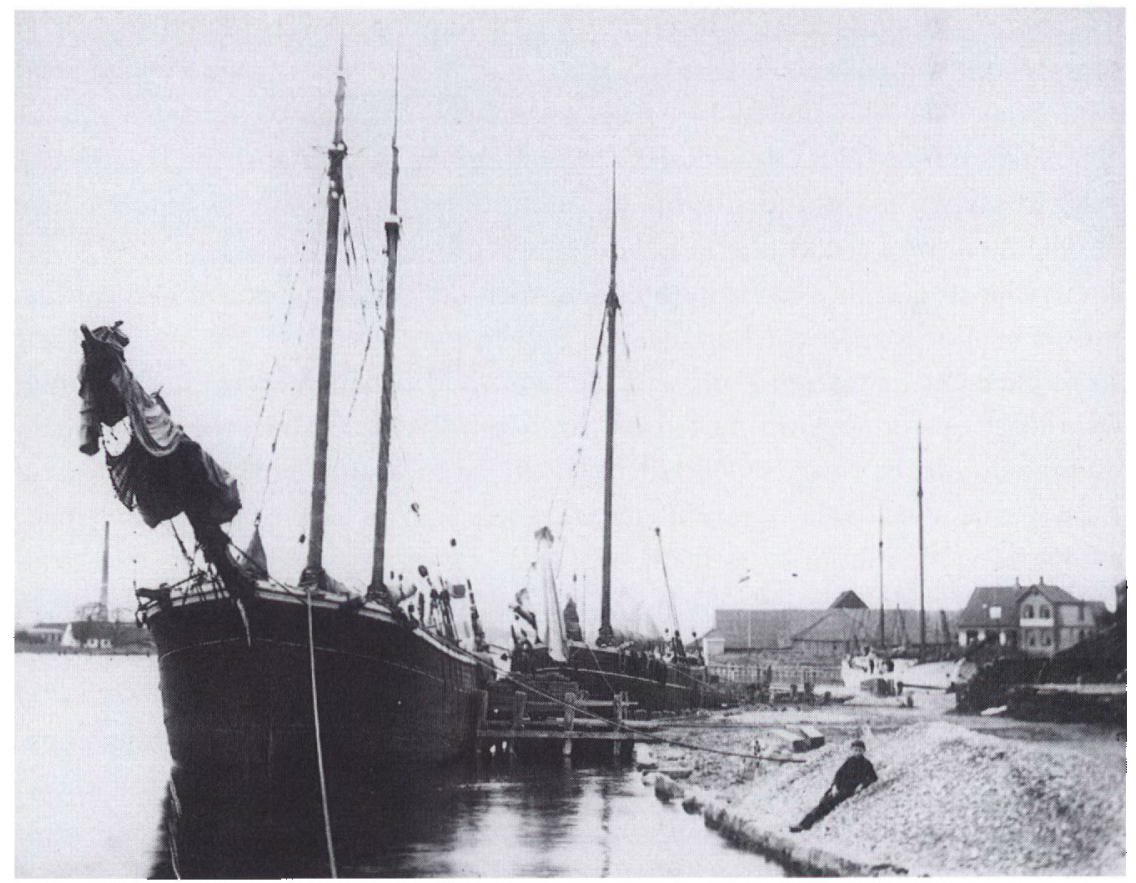

Havnen i Egernsund med sejlskibe, teglvarker og fargekro. Foto C.C. Biehl. Historiske Samlinger for Sonderjylland.

Tilsidst fandt vi dog den rigtige. Efter lang rådslagning, om vi skulle gøre alarm eller ligge ude om natten, besluttede vi dog det første.

Snart kom Phillipsen også ud i døren, og da han havde set hvem det var,

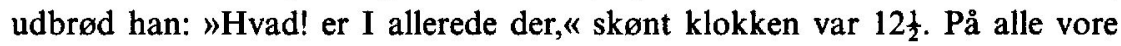
undskyldninger over at være kommet så sent, svarede han med at sætte skinke og kaffe på bordet, og vi fik et forsvarligt foder. Vi fortalte så vore hændelser, der forekom ham meget morsomme, og kom først i seng langt ud på natten.

\section{Mandag den 24. juli 1893}

Om morgenen kørte vi med Philipsen til Dybbøl, og herfra gik vi i det mest storartede vejr til Sandbjerg. Her gik vi ind hos Ort, og blev af sønnen vist omkring i den smukke have. Slottet tilhører grev Reventlow på Brahetrolleborg, som imidlertid aldrig bor der. Haven, der strækker sig ned imod Alssund, er et yndet udflugtssted for Sønderborg og omegnen. Men alt her er også udmærket smukt, skønt i lille stil. Alssund, en stor mølledam, slottet og haven samt de store skove tager sig udmærket ud, og det hele danner en idyllisk lille plet. 
Fra haven gik vi langs med sundet til "Storskoven«. Indgangsleddet var malet rødt og hvidt, noget som vi for første og sidste gang så i Sønderjylland; men grunden er jo den, at godset er privat, og myndighederne har altså ikke ret til at forbyde de danske farver på vedkommende ejendom. Her fra Storskoven skød prøjserne over sundet på de danske tropper, og endnu kan man tydeligt se de dybe huller, hvori de gravede sig ned, mens også træstammerne rundt om er fulde af navne indridsede med bajonetten af de prøjsiske soldater. Her fra Storskoven var det også, at prøjserne i 64 satte over til Als i deres små både, trods det, at et par skud fra panserskibet "Rolf Krake» havde kunnet bore dem alle i sænk. Men forresten må situationen ikke have været behagelig for dette skib; thi Alssund er her så smalt, at de prøjsiske kugler fra landsiden næsten alle ville kunne ramme skibet, hvis det skulle begynde på at fyre, og granater og kanonkugler ville have en frygtelig virkning på den korte afstand.

Efter at vi havde spist til middag, blev vi af en fisker sat over Alssund til den lige overfor Sandbjerg liggende Kjærvig. Herfra ville vi så gå til Sønderborg, og såfremt Philipsen ikke var dér med vognen, skulle vi sejle med damper lige til Skellemark.

Vi gik altså frem i den retning, hvor vi mente Sønderborg måtte ligge; men imidlertid begyndte det at småregne, og småregnen blev efterhånden til storregn. I dette vejr nærmede vi os Sønderborg, men kort før vi kom til byen, var vi oppe på en nu nedlagt skanse, Engelhøj, som strakte sig over et område af 20 tdr. land, så det var en ordentlig stor en. Nu så den ganske fredelig ud og var for en stor del bevokset med korn. Den vide udsigt, man ellers har deroppefra, så vi ikke stort til, da regnen og tykningen spærrede den.

Endelig kom vi til Sønderborg og fandt efter nogen anstrengelse kirkegården, som vi var inde på. Her ligger overmåde mange soldater begravede. En mærkelighed ved alle tyske grav- og sejrsmonumenter er, at der altid uden om dem er stukket kanoner med mundingerne nedad i jorden, og disse kanoner er indbyrdes forbundne med jernlænker, så det danner et slags gitter. Men det hele ser frygtelig krigerisk og martialsk ud, hvorimod de danske grave altid er langt hyggeligere og pyntede med Dannebrogssløjfer og grønt. Vi så imidlertid ikke noget til Philipsen og tog derfor billet til Skelle, men kort efter kom han og efter megen snakken med billetkassereren fik vi vore penge tilbage.

Kort efter, da vi stod ved havnen og beregnede vore finanser, opdagede Svend, at han havde mistet en timark i guld. Der blev naturligvis stor bestyrtelse, og vi måtte nu foreløbig give afkald på at nå helt til Dannevirke; over hals og hoved måtte vi skynde os hjem for de penge, vi havde tilbage, og nu da vi havde det så udmærket og morede os så godt, var det sandelig ikke rart at rejse bort fra hele herligheden. Det var rigtignok en rar redelighed! Og det 
var heller ikke rart at fortælle denne sørgelige efterretning til Philipsen, som havde gjort så meget for os, og som vi vidste ville blive bedrøvet over vort uheld.

Det anede os straks, at Svend havde givet sin 10-mark ud i stedet for en 2groschen ved Ekernsund, da vi nær aldrig havde fået billet; og der var altså dog nogen rimelighed for at billetøren, hvis han var ærlig, ville give os den tilbage, men det havde han ikke set ud til at være, og vort håb om nogensinde at se 10-marken igen var noget svagt. Lidt efter fik vi de sjunkne livsånder oplivede af en kop kaffe, men humøret var ikke det bedste, da vi kort efter i øsende regnvejr kørte igennem Broager og Gammelgab til Skelle. Den arme Svend ventede hele tiden på at få lejlighed til at fortælle Philipsen vort store tab, men det var ikke let at få det sagt, og forst den næste dag fortalte han det.

\section{Tirsdag den 25. juli 1893}

Vi havde imidlertid regnet ud, at de penge, vi havde, kunne strakke til til en tur til Flensborg. Dér havde jeg så nogle slægtninge, som jeg ganske vist ikke anede, hvor boede; men det tænkte vi, at vi nok skulle finde, og da jeg tilfældigvis så $i$ en avis, fandt jeg netop fætter Kristians adresse $i$ et avertissement.

Philipsen havde jo imidlertid endnu ikke hørt vor "Markedsberetning", men det havde hele tiden været vor mening at holde os i ro hos ham om tirsdagen og samle kræfter til den lange tur ned til Dannevirke; derfor kunne vi altså godt blive ved denne plan, hvad vi også gjorde og begyndte hviledagen med at sove til kl. 10. Efter kaffen gik vi ned til stranden, og badede. Vejret var ganske udmærket, og det var en storartet nydelse at ligge og dase på den stejle skrænt ned til Flensborg fjord, og holde øje med de mange, mest mindre skibe, der sejlede til og fra de mange teglværker ved kysten.

Efter middag var vi ude at svømme, men bunden var ikke rigtig god på visse steder. Alligevel var badet udmærket og vi begyndte allerede så småt at forsone os med tabet af vor timark. Efter badet var Gram så uheldig at miste sin hat, som fløj ind i en havremark og først efter at have gennemsøgt marken på kryds og tværs og anstillet forsøg med Svends hat, hvor den muligvis kunne være falden, fandt vi den lige indenfor gærdet ud mod stranden, hvor vi havde været umådelig mange gange. Denne nye uvejrssky, som truede med at gøre vort uheld endnu større, var altså heldigvis trukket over, og da vi senere hen opdagede, at Svend havde mistet sin dolk, syntes vi næsten det var i sin orden; thi lidt uheld måtte vi da have.

Da hatten lykkelig var fundet, gik vi med Philipsen til en hr. Rosendal i Gammelgab. Philipsen var nemlig blevet stævnet, fordi han ved et møde havde 
læst digtet "Niels Kjeldsen« op, og navnet på Niels Kjeldsens morder, som han havde været uforsigtig nok til at læse op, havde været skyld $i$ anklagen. Han ville nu rådføre sig med denne Rosendal, der forresten var en meget gammel mand. Hans kone, som han havde fået fat i på en meget mærkelig måde, var derimod yngre og meget livlig.

Her traf vi fru Fabricius fra Broager Mejeri og her fik Svend endelig lejlighed til at fortælle om 10-marken. Vi blev naturligvis beklaget meget af selskabet, og kort efter forsvandt fru Fabricius; men lidt efter kom en lille dreng ind med en seddel fra hende, hvorpå der stod, at fru Rosendal på hendes vegne skulle give os 10 mark. Vi blev behageligt overrasket, men ville naturligvis kun modtage pengene som lån. Overmåde glade vandrede vi så hjem igen og glædede os til den storartede tur den næste dag over Flensborg, Oversø og Isted til Slesvig. Vort humør blev endnu bedre, da Philipsen erklærede, at han efter den beskrivelse, vi havde givet af billettøren på damperen, nok vidste, hvem det var og ovenikøbet vidste, at det var en ærlig mand, så vi gik den aften i seng $i$ et betydelig bedre humør end dagen i forvejen.

\section{Onsdag den 26. juli 1893}

Om morgenen tidlig blev vi vækket kl. 5, og efter at vi alle 3 var blevet forsynet med en vældig pakke smørrebrød hver, gik Gram og jeg til Brunsnæs, mens Svend og Philipsen begav sig til Ekernsund, hvorfra de skulle sejle til Sandager. Her skulle de træffe sammen med Gram og mig og ville så i Flensborg se at få den mistede 10-mark tilbage. Gram og jeg travede altså den ikke særlig korte vej til Brunsnæs, men vi var ikke langt fra at ønske, at den var længere endnu. Vejen gik nemlig for en stor del langs med Flensborg fjord, og når vi kom lidt længere op $i$ landet havde vi den mest storartede udsigt til alle sider. Når man dertil føjer, at det var tidligt om morgenen, og solen endnu ikke havde fået duggen af marker og træer, kan man nok forstå, at det var en storartet tur.

Da vi kom til Brunsnæs, var der endnu nogen tid, inden damperen kom, og vi satte os derfor ned på broen i ro og mag og nød tilværelsen. Imidlertid kom damperen, og fra Brunsnæs sejlede vi så forbi halvøen Holnæs til Sandager, hvor vi stødte på Svend og Philipsen. Gram og jeg havde i sinde at stå af i Lyksborg for at se slottet og den kønne omegn, og først med det næste skib at sejle til Flensborg, hvor vi så alle tre skulle se at finde min kære fætter, der skulle bo i eller på noget der hed Holm. Efter at have set Flensborg var det så vor mening at gå derfra gennem Sankelmark og Oversø til gården Aagaard, hvor vi håbede at kunne tilbringe natten hos "gamle Tofte«. Han havde ganske vist solgt gården, men Philipsen mente, at han endnu boede på den. ${ }^{15}$ 


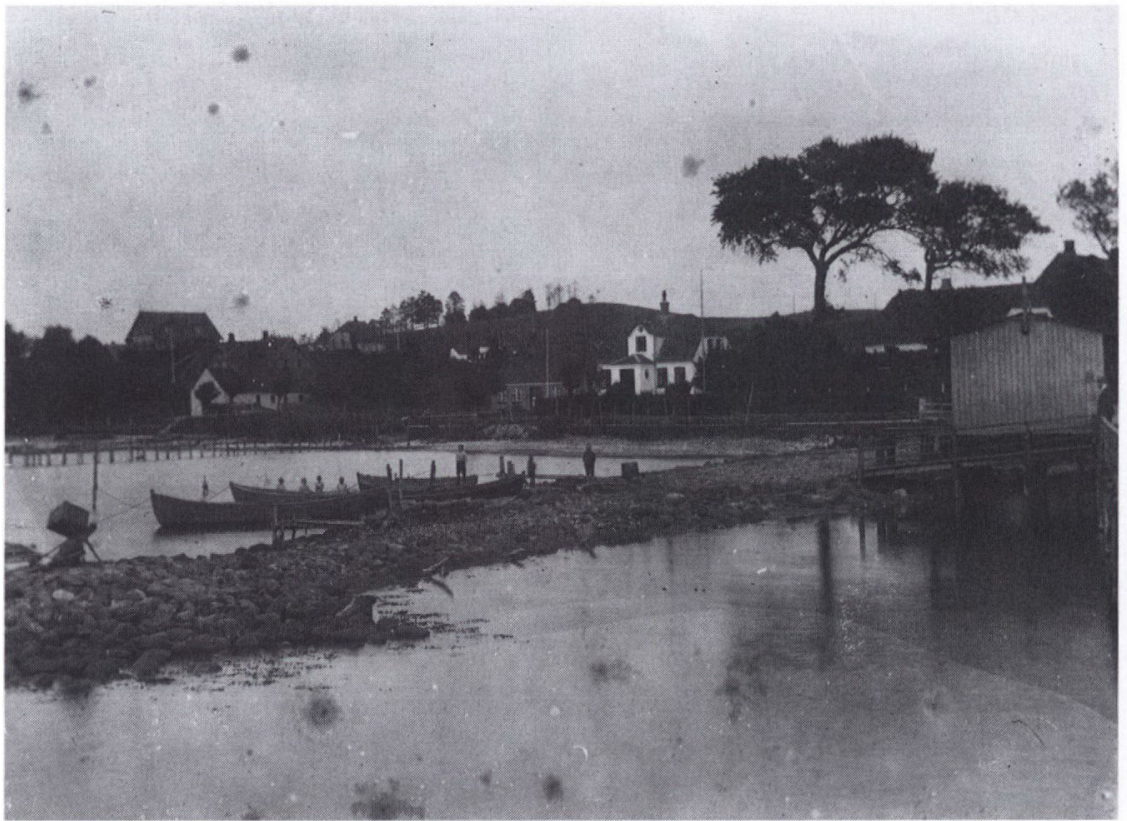

Havnen i Brunsnass o. 1920. Dumpskibsbroen ses yderst til hojre. Biehl foto i Historiske Samlinger for Sonderjylland.

På sejladsen fra Sandager til Lyksborg fik vi et par byger, som dog imidlertid snart trak over, og solen skinnede igen, da Gram og jeg stod af i Lyksborg efter at have taget afsked med vor flinke vært Philipsen. Vi 2 så os altså om dér ved Lyksborg. Lige ved stranden lå 2 valdige badehoteller, og hele strandbredden var opfyldt af badegæster, der promenerede langs med stranden. Lyksborg er nemlig et meget søgt badested, og især fra Hamborg kommer mange rigmænd og tilbringer badesæsonen her. Thi ikke blot badene er gode, men omegnen og beliggenheden er en af de skønneste ved hele Flensborg fjord; og det vil sige meget. Forbi en hel del pensionsanstalter vandrede Gram og jeg afsted for at finde Lyksborg Slot. På denne vandring lagde vi mærke til, hvor stor forskel der var på det fuldstændig danske land nord for fjorden og det næsten fuldkomment tyske Angel syd herfor; og det var kun meget sjældent, vi hørte andet end tysk i omegnen af Lyksborg.

Igennem flere skove, hvor vi rigtignok blev skilt fra hinanden, kom vi da til slottet. Det er en stor hvidkalket bygning, med nogle små spidsgavlede tårne, der $\mathrm{i}$ og for sig selv er temmelig grim, men beliggende $\mathrm{i}$ en lille sø og omgivet af skov gør den dog et smukt indtryk. Her var det også, at Frederik 


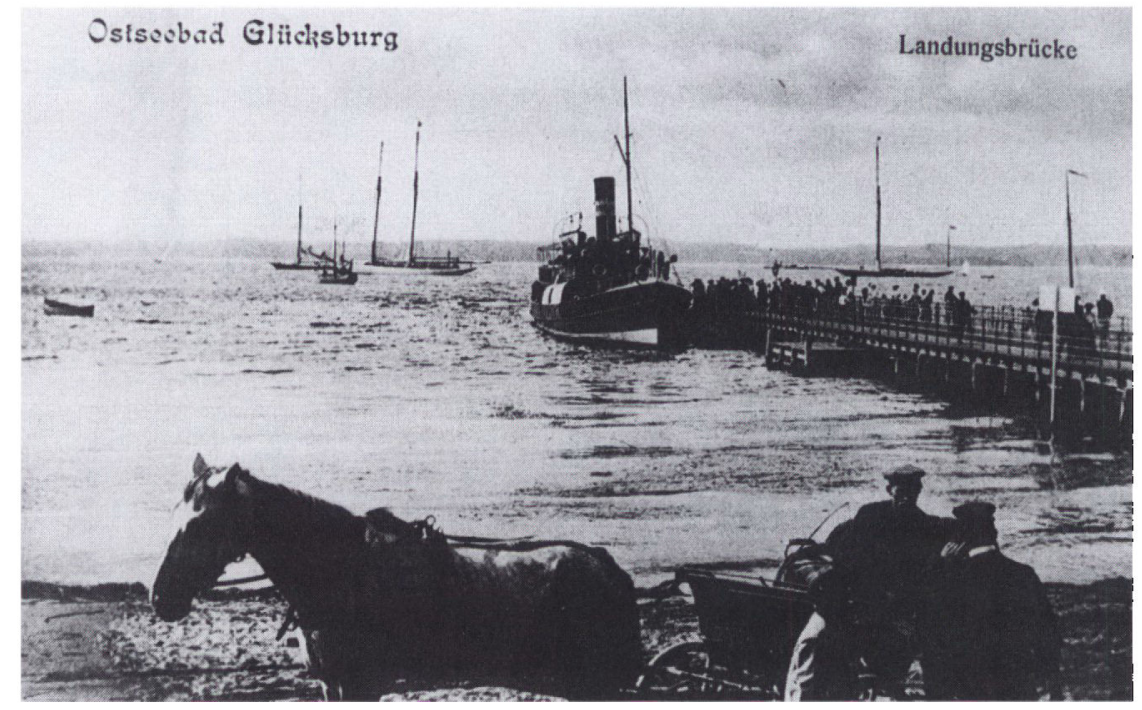

Dampskibet lagger til i Lyksborg. Foto o. 1900 i Dansk Centralbibliotek for Sydslesvig.

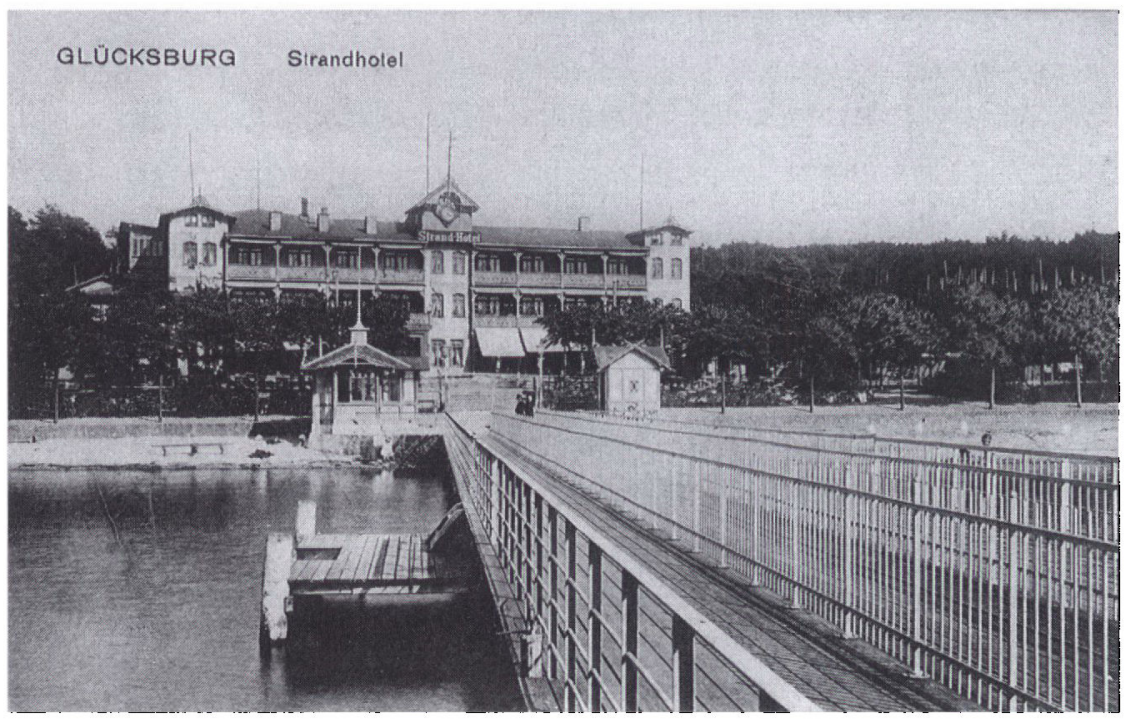

Fra sidst i 1800-d̊rene satte de store badehoteller og de mange badegaster prag pd Lyksborg. Postkort i Dansk Centralbibliotek for Sydslesvig. 
d. 7. meget gerne opholdt sig, og hvor han som bekendt døde. Man påviser endnu et stort træ, hvor kongen skal have siddet med sin medestang og fisket i søen. Igennem den lille flække gik vi tilbage til dampskibsbroen igennem skoven, og da der endnu var nogen tid, indtil damperen kom, benyttede vi os af lejligheden til at gå en tur langs med stranden $i$ det dejlige vejr.

Imidlertid kom damperen, og vi sejlede så ind til Flensborg. Skibet var propfuldt, og blandt passagererne var den tyske kejsers moder og flere fyrstelige personer, som sad ganske ugenert på dækket og lod sig beglo af alle deres medrejsende. På dampskibsbroen i Flensborg traf vi Svend, som ganske rigtig havde fået sin 10-mark igen. Som belønning for billettørens arlighed forærede han ham den ene mark til at slå til Søren for, og de 10 mark, Svend havde lånt, havde han naturligvis sendt med Philipsen tilbage til deres ejerinde.

Fra skibsbroen begav vi os op i byen; men uheldet ville, at det netop skulle begynde at regne, og vi måtte først stå i tørvejr $i$ en port, indtil bygen trak over. Straks ved broen lå en smuk stor bygning, "Flensborg Avis《's trykkeri, og den skal være en slem torn $i$ øjet på tyskerne. I nærheden af den ligger "Sommers Hotel«, der altid besøges af de danske. Igennem det lille stræde kom vi herfra op på den lange gade, som strækker sig igennem hele byen. Den er meget livlig, og det at der findes mange gamle bindingsværkshuse og højst aparte gamle bygninger, giver den et særligt præg.

Op ad denne gade gik vi altså og spekulerede på, hvordan vi skulle finde min fætters bolig. Pludselig ser jeg på et gadehjørne ordet »Holm«, og snart havde vi fundet husnummeret. Uheldigvis var min fætter selv ikke hjemme, og kun hans kone og moder tillige med et par tvillinger opholdt sig i huset. Her sad vi så et par timer og fortærede et par glas vin og nogle kager, mens samtalen gik højst bedrøveligt. Svend og Gram sagde ikke et levende ord, min "kusine« kunne næsten ikke dansk, og bedstemoderen talte et frygteligt sprog, som det næsten ikke var til at forstå. Samtaleemnet om familien var snart opbrugt, og vi ventede nu på at blive budt på middag, man der kom ingen indbydelse, og tilsidst rejste vi os da for at gå.

Efter at have set tvillingerne, gik vi så ud $\mathrm{i}$ byen for på egen hånd og ved hjælp af rejsebogen at finde byens seværdigheder. Vi gik først på opdagelse efter kirkegården, som vi langt om længe fandt. På denne tur kom vi forbi mange højst aparte bygninger, blandt andet en, der var bygget som en gammel borg fra middelalderen og vist var byens rådhus. Ligeledes så vi den nye $\mathrm{og}$ smukke latinskole og de store kirker. På kirkegården opholdt vi os en lang tid. Over de danske krigergrave er der jo nu opkastet en hel kæmpehøj med marmortavler, hvorpå navnene på de bekendte mænd er skrevet. Her hviler 3.000 soldater, der alle er faldet i slaget ved Isted, og på marmortavlerne læser man derfor navne som Schleppegrell, Trepka, Læssø og mange flere. Graven, 


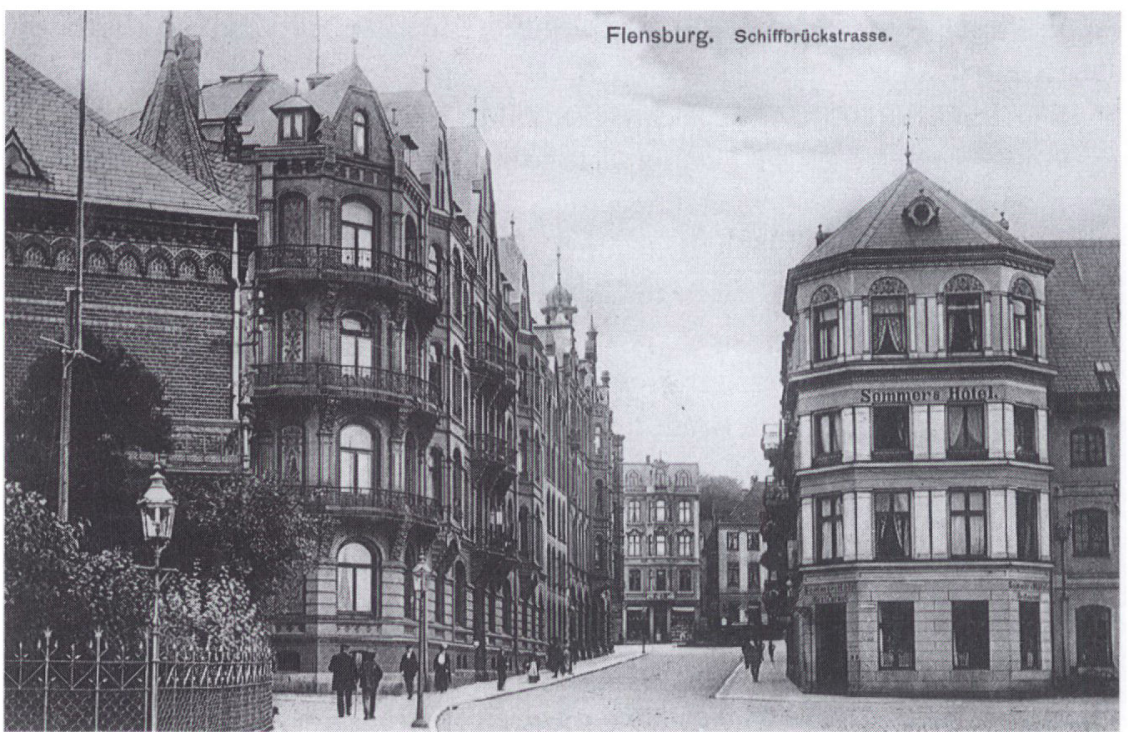

I Flensborgs Skibbrogade lå til højre "Sommers Hotel", som blev besegt af mange danske. I ejendommen til venstre i forgrunden - Skibbrogude 8 - havde Flensborg Avis' redaktion, trykkeri og ekspedition til huse i årene 1885-97. Postkort i Dansk Centralbibliotek for Sydslesvig.

der er helt overvokset med grønt og prydet med Dannebrogssløjfer, er overmåde smuk, og en valdig kampesten, der er rejst over faldne slesvig-holstenere og er alt andet end køn, gør synet af den danske krigergrav endnu smukkere ved at fremhæve modsætningerne.

Det var ikke let at rive sig løs fra denne plet, men vi måtte jo af sted og se at komme ned til Aagaard, der ligger et stykke øst for chausseen til Slesvig, en mils vej syd for Flensborg. Det gjaldt nu om at finde Rødegade, hvorfra chausseen går imod syd, og efter nogen søgen fandt vi den også. Da vi var kommet et stykke udenfor byen, lagde vi os ned i grøften og spiste vort smørrebrød, men vi havde også gået lige fra kl. 5 om morgenen til kl. 1 uden at have fået andet end et par glas vin, så man kan nok forstå, at vi trængte til noget at styrke os på.

Styrkede af måltidet begav vi os igen på vandring. Vi var nu i det tyske distrikt og syd for grænselinien mellem dansk og tysk, som går fra Flensborg og i en tunge imod syd til Tønder. Da vi havde gået en mils vej, kom vi til Sankelmark og Oversø, der jo er så bekendte fra de 2 slesvigske krige. Når man er kommet forbi Bilskov kro, har man til højre 2 små skove, adskilte ved en eng, og bagved disse skove ligger søen med den så berømte mose, hvor det 2. jægerkorps [?] i 1848 under oberstløjtnant Styrup kæmpede imod en mange 
gange større troppestyrke med den største tapperhed. Styrup faldt og ligger begravet på Oversø kirkegård.

16 år senere stod der ligeledes her en kamp mellem en lille dansk styrke og en stor overmagt. Det var 1.ste og 11.te regiment, der her standsede østrigernes og prøjsernes forfølgelse på tilbagetoget fra Dannevirke. På den mark, der skråner ned mod søen, blev den morderiske kamp leveret, hvoraf Simonsen har givet en skildring $i$ sit bekendte store maleri. Til venstre ligger nu en lyngklædt bakke, og på den var det at general Max Müller holdt under kampen, og hvorfra han let kunne overskue slagets gang. Oppe på denne bakke så vi, at der ragede noget frem ligesom taget af et hus, men da vi kom hen til det formentlige hus, viste det sig, at det var et østrigsk mindesmærke over deres faldne krigere. Det var ikke kønt, men så ganske mærkeligt ud, og var som alle tyske mindesmærker omgivet af et gitter af kanoner, hvis mundinger var stukket ned $\mathrm{i}$ jorden. Til højre $\mathrm{i}$ skovbrynet stod et andet østrigsk monument og lidt længere henne et dansk, som er oprejst af en privatmand i København og som alle danske mindesmærker var prydet med dannebrogssløjfer.

Efter rigtig at have studeret valpladsen her gik vi til Oversø by, som ligger lidt længere imod syd. Kirken er meget ejendommelig. Den er nemlig helt bygget af kampesten og kun på den ene side findes et par ganske små vinduer. Tårnet er rundt og ikke højere end selve kirken, og det hele ligner mere en gammel borg med skydehuller og ganske små vinduer. Den er meget gammel

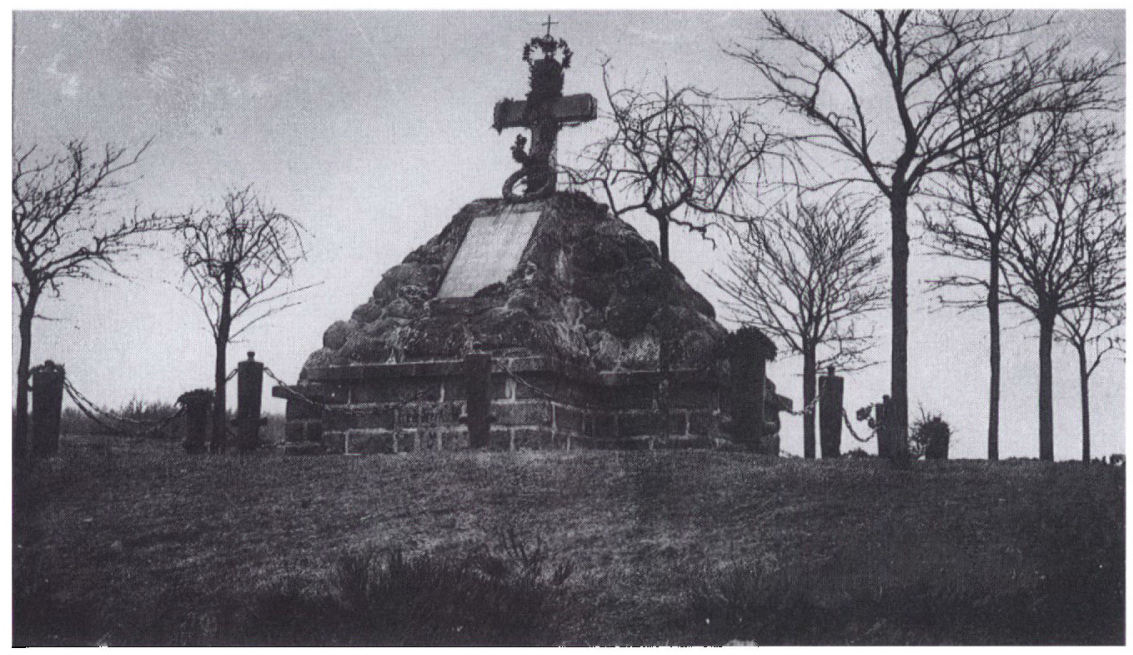

Det ostrigske mindesmarke ved Sankelmark/Overso. Kanoner, hvis mundinger er stukket ned i jorden og forbundet med jernkader, danner krans om mindesmarket. Foto Th. Thomsen i Dansk Centralbibliotek for Sydslesvig. 
og har i den ældste tid tjent beboerne til forsvar i krigstid, hvad også dens hele bygningsmåde viser.

Igennem byen løber Trenen, og syd for den gik vi imod øst til Aagaard. Det var nu henimod aften, og landskabet her så mere uciviliseret ud, med moser og lyng belyst netop af den nedgående sols stråler, da vi holdt vort indtog på Aagaard, hvor de "sønderjyske piger« er fra. Tofte var, som vi havde frygtet for, rejst bort, og den nye ejer, Schmidt, kunne ikke have os om natten, da han ikke var kommet $i$ orden på gården endnu. Her spiste vi så til aften og begav os meget slukørede på vej igen. Efter megen rådslagning om vi skulle blive i Oversø kro den nat eller ikke, vedtoges det at gå til Helligbæk kro, som ikke ligger langt fra Isted og her tilbringe natten. Næste dag ville vi så bese valpladsen ved Isted og herfra gå tilbage til Flensborg. Thi vi kunne nok indse, at pengene ikke ville slå til lige til Dannevirke på grund af alle disse uventede udgifter.

Vi begav os altså afsted og fulgte bestandig vejen til Slesvig. Jeg vil ikke nægte, at vi begyndte at blive lidt trætte, men vi havde jo også gået hele dagen. Chausseen går igennem landsbyerne Smedeby og Stenderup igennem nogle små skove. Et stykke vej syd herfor ligger Helligbæk kro lige ved åen af samme navn. Da vi kom hertil, var det langt ud på aftenen, men efter kortet var der ikke så langt til Isted kro, og vi mente, at vi ligeså godt kunne gå det stykke vej til; vi ville så have det meget nemmere næste dag. Vi gik og gik, men det forekom os, at vi aldrig kom til kroen. Månen stod op og tågerne rejste sig på de store enge og moser rundt om, træthed og mine ømme fødder gjorde ikke tilværelsen videre behagelig, og humøret blev kun holdt oppe ved tanken om den dejlige søvn vi ville få, når vi kom til Isted kro. Over en stor hede, Bøgemosen, opfyldt af kæmpehøje, nærmede vi os en stor skov, foran hvilken kroen måtte ligge.

Endelig langt om længe nåede vi den, men alle var i seng, og alt hvad vi bankede hjalp ligemeget. Endelig kom jeg hen til et vindue, og her fik jeg vækket gårdskarlen. Men på alle mine spørgsmål og anmodninger om husly svarede han: "Nein! Nein! es ist zu spät«! og da jeg blev ved at trænge på, ville han tilsidst slet ikke tale med mig. Nu var gode råd dyre. Ude på vejen blev der holdt krigsråd, og det besluttedes at gå tilbage til Flensborg igen, da vi i den fugtige og kolde nat ikke turde ligge ude i lyngen, og da der ikke var nogen hytte $\mathrm{i}$ stor omkreds. Og hvem ville også midt om natten modtage sådan 3 landevejsrøvere.

I en overmåde uhyggelig stemning foretoges tilbagetoget, ad samme vej, som hæren gik i 1864 . Svend og Gram måtte hele tiden dunke mig i ryggen og hive i mig, for at jeg ikke skulle falde helt i søvn, og alle var vi så trætte, som et menneske kan blive. Tågen lagde sig over hele egnen, og i søvne så vi 
for os bjerge og et oprørt hav, og tågen antog alle mulige sære skikkelser som ligesom i drømme gled forbi og afløstes af andre af anden form. Fuldstændig sovende gik vi videre, slingrende fra den ene side af vejen til den anden, fuldstændig ligeglade og sløve. Pludselig mærkede jeg, at jeg sank helt sammen, og da jeg åbnede øjnene, så jeg de to andre langt borte i tågen, så jeg må have stået og sovet en stund, indtil en fornemmelse, som om al spændkraft og alle muskler slappedes, vækkede mig. Kun én gang, da vi troede at være gået vild, vågnede vi lidt op, men da det viste sig, at vejen var rigtig, blev slappelsen og trætheden endnu værre, og den sidste mil måtte vi sætte os ned hver 10. minut og hvile. Når vi så havde sovet en stund, slingrede vi videre, og med fordrejede træk og uden næsten at kunne kende os selv, dinglede vi ind i Flensborg kl. 5 om morgenen.

\section{Torsdag den 27. juli 1893}

Med megen besvær fandt vi banegården, og her sov vi så et par timer på bænkene. Da jeg vågnede var det, som om hele min krop var mørbanket, jeg rystede af kulde og var umådelig skidt tilpas. Men en kop kaffe med det lækreste smørrebrød gjorde storartet virkning, og jeg følte mig udmærket vel igen.

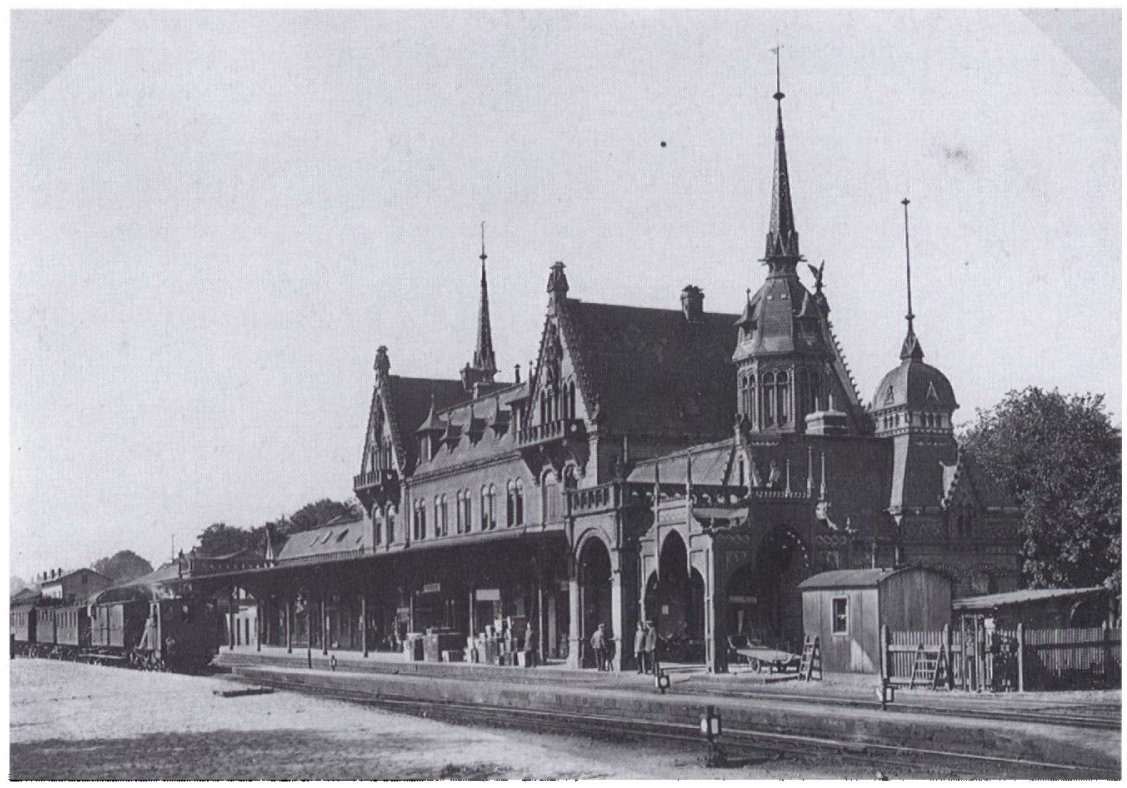

Statsbanegården $i$ Flensborg blev bygget $i 1885$ af arkitekt J. Otzen i nygotisk stil og nedbrudt 1955. Foto Th. Thomsen i Dansk Centralbibliotek for Sydslesvig. 


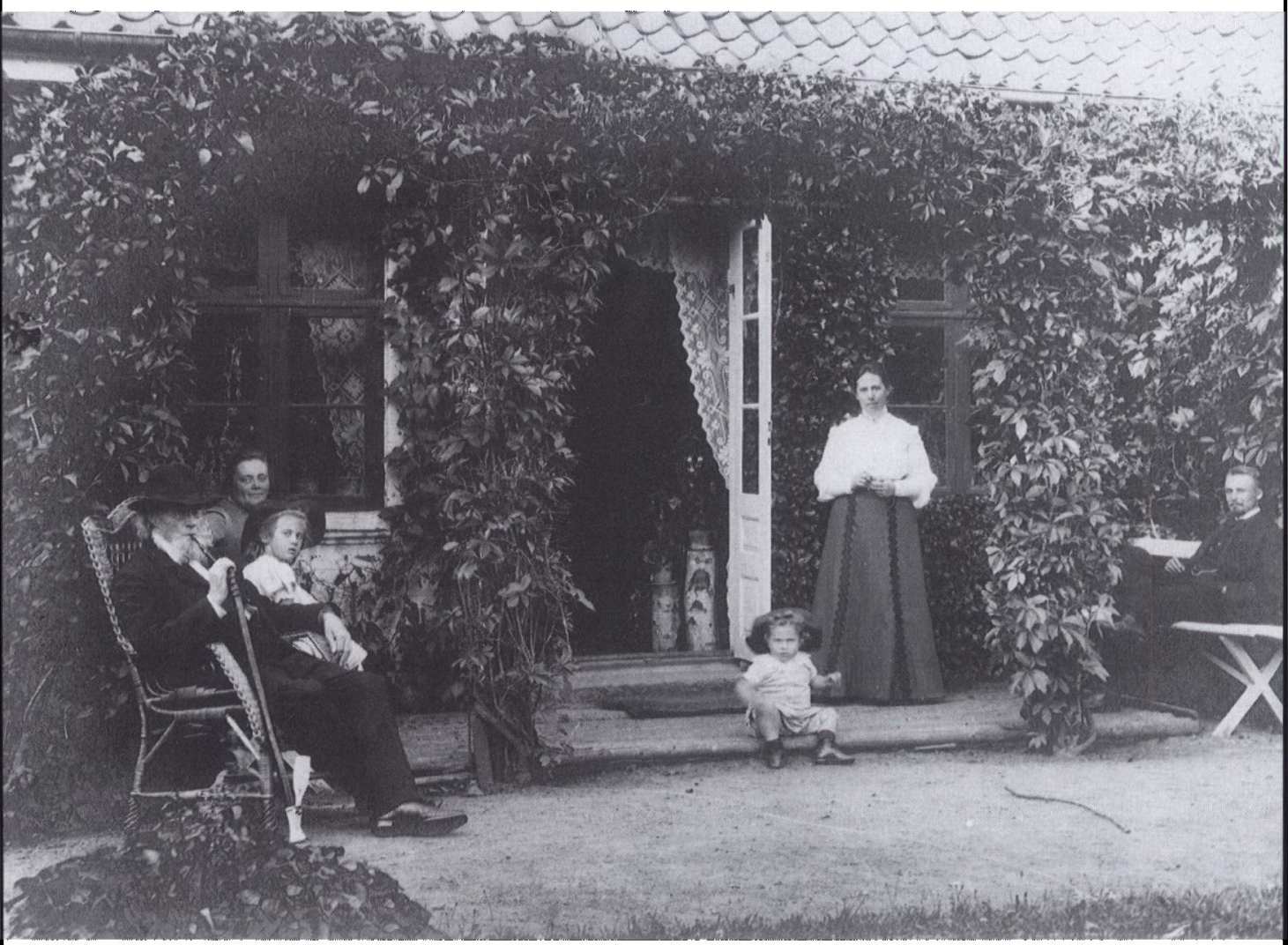

En sommerdag i Norre Lyndelse prastegård. Til venstre ses pastor $C$. N. Lorenzen, med grundtvigianerhat og lang pibe, til hojre sonnen Vilh. Lorenzen, hjemme på besøg. Pastor Lorenzen var fodt og opvokset i Logumkloster og folte sig hele sit liv knyttet til Sonderjylland. Interessen for sonderjyske forhold gik i arv til sonnen. Foto sidst i 1890'erne i privateje.

Vi tog os nu en tur langs med fjorden, og ude ved »Østersøbadet" lagde vi os ned og tog en lille skraber, der friskede os endnu mere. Som frokost drak vi en flaske münkenerøl hver, som også gjorde udmærket virkning, og vi sad så en stund og ventede på, at toget skulle gå til Haderslev, hvorfra vi ville spadsere til Grønninghoved ved Mosvig og Skamlingsbanken, hvor tante og hele familien lå og badede. Toget var imidlertid nær kørt uden os, og kun ved et rent tilfælde kom vi med.

Jernbanevognens skrumplen dyssede os imidlertid snart i søvn, og mens vi sov, kørte toget forbi Vojens, hvor vi skulle have skiftet tog. Pludselig vågnede jeg, og da jeg ser ud af vinduet, ser jeg en mølle og nogle omgivelser, jeg 
mente at skulle kende. Snart efter holdt toget også ved Vamdrup. Vi var altså sovende kørt til Danmark igen og havde i et par timer tilbagelagt den samme vej, som vi kort før havde været 8 dage om.

\section{NOTER}

1. Dansk Biografisk Leksikon 3. udg., bd. 9, 1981 s. $130 \mathrm{f}$.

2. Dagbogen fylder i sin helhed 70 håndskrevne sider $\mathrm{i}$ en notesbog $(16 \times 10,5 \mathrm{~cm})$. Teksten gengives i narvarende udgave $i$ let moderniseret form.

3. Svend og Gram Nygaard, antagelig sønner af Lavrids Nygaard (1848-1916), prast i Gimlinge, og Augusta Birkedal (1839-1917), søster til Vilh. Lorenzens mor Agathe (1846-1884). De tre fatres bedstefar var prasten Vilh. Birkedal, Ryslinge.

4. Claus Nicolaj Lorenzen (1835-1905). Hans forhold til Sønderjylland omtales af Johannes Clausen fra Vonsild i hæftet: C.N.Lorenzen. Træk af hans liv og talerne ved hans jordefærd (Odense 1905) s. 26.

5. Volle Lorenzen, derd 1844.

6. Kilde: Jørgen Nielsen: Pastor C.N.Lorenzen, i mindeskriftet s. 1, jvfr. note 4.

7. Kirstine Nicolajsen, død 1862.

8. Vilhelm Birkedal (1809-1892) prast og forfatter, se Dansk Biografisk Leksikon 3. udg., bd. 2, 1979 s. $154 \mathrm{ff}$.

9. Gerhard Christoph Krogh (1785-1860), født på Åstrupgård, 1849 udnævnt til overgeneral, ledede 1850 den danske hær i slaget ved Isted, 1851 kommanderende general i Slesvig og Holsten.

10. Formentlig fejlskrivning for Matthias Frederik Christiansen, gårdejer i Ragebøl.

11. Heinrich Ferdinand Emil Claussen var præst i Dybbøl 1865-1902. Han var udpræget dansk af sindelag. F.eks. kæmpede han for at beholde dansk sprog i skolens religionsundervisning.

12. Andreas Andresen (1842-1914), gårdejer, Rojhus i Skelde. Hans erindringer er udgivet af Hans Schultz Hansen i Sønderjyske Årbøger 1990 s. 101-156.

13. Peter Philipsen var en af Andresens narmeste venner. Han havde mange gode forbindelser $j$ Kongeriget og er hyppigt omtalt i Andreas Andresens erindringer, jvfr. note 12.

14. A.N.C. Ohrt (1829-1917), godsinspektør pă Sandbjerg.

15. Den danske "Ågård Landboskole« i Oversø sogn åbnede i maj 1863 med cand. pharm. J.A. Viinsted som leder. 1869 overlod han ledelsen til Hans Mikkelsen Tofte, som hidtil havde varet degn og lærer i Flensborg. Tofte drev skolen videre indtil $1889 \mathrm{og}$ måtte i 1892 sætte ejendommen på tvangsauktion.

Toftes to døtre blev kendt som »de sønderjyske piger«. 